\title{
Use of agro-industrial by-products containing tannins for the integrated control of gastrointestinal nematodes in ruminants
}

\author{
Hervé Hoste ${ }^{1, *}$, Griselda Meza-OCampos ${ }^{1}$, Sarah Marchand ${ }^{1}$, Smaragda Sotiraki $^{2}$, Katerina Sarasti ${ }^{2}$, \\ Berit M. Blomstrand ${ }^{3}$, Andrew R. Williams ${ }^{4}$, Stig M. Thamsborg ${ }^{4}$, Spiridoula Athanasiadou ${ }^{5}$, Heidi L. Enemark ${ }^{6}$, \\ Juan Felipe Torres Acosta ${ }^{7}$, Gabriella Mancilla-Montelongo ${ }^{7}$, Carlos Sandoval Castro ${ }^{7}$, Livio M. Costa-Junior ${ }^{8}$, \\ Helder Louvandini ${ }^{9}$, Dauana Mesquita Sousa ${ }^{8}$, Juha-Pekka Salminen ${ }^{10}$, Maarit Karonen ${ }^{10}$, Marika Engstrom ${ }^{10}$, \\ Johannes Charlier ${ }^{11}$, Vincent Niderkorn ${ }^{12}$, and Eric R. Morgan ${ }^{13}$
}

${ }^{1}$ Université de Toulouse, UMR 1225 IHAP INRAE/ENVT, 31076 Toulouse, France

${ }^{2}$ HAO/DEMETER, Campus Thermi, 57001 Thessaloniki, Greece

${ }^{3}$ Norwegian Centre for Organic Agriculture, 6627 Tingvoll, Norway

${ }^{4}$ University of Copenhagen, 1870 Frederiksberg C, Denmark

5 Scotland's Rural College (SRUC), Easter Bush, EH25 9RG, United Kingdom

${ }^{6}$ Norwegian Veterinary Institute, 1400 Ås, Norway

7 CONACYT-Facultad de Medicina Veterinaria y Zootecnia, Universidad Autónoma de Yucatán, Carretera Mérida-Xmatkuil km 15.5, Mérida, Yucatán 97000, México

${ }^{8}$ Laboratório de Controle de Parasitos, Centro de Ciências Biológicas e da Saúde, Departamento de Patologia, Universidade Federal do Maranhão, São Luis, Maranhão, MA 65080-805, Brazil

${ }^{9}$ Laboratório de Nutrição Animal, Centro de Energia Nuclear na Agricultura, Universidade de São Paulo, 13400-970 Piracicaba, São Paulo, Brazil

${ }^{10}$ Natural Chemistry Research Group, University of Turku, 20014 Turku, Finland

${ }_{11}$ Kreavet, Hendrik Mertensstraat 17, 9150 Kruibeke, Belgium

${ }_{11}^{12}$ Université Clermont Auvergne, INRAE, VetAgro Sup, UMR Herbivores, 63122 Saint-Genes Champanelle, France

${ }^{13}$ School of Biological Sciences, Queens University, Belfast, BT9 5DL Northern Ireland, United Kingdom

Received 26 November 2021, Accepted 26 January 2022, Published online 28 February 2022

\begin{abstract}
Previous studies have illustrated that different bioactive legume fodders containing condensed tannins might represent one of the options for integrated sustainable control of gastrointestinal nematodes (GIN) in ruminants, which may help address the worldwide development of resistance to synthetic anthelmintics. More recently, impetus has been given to assess the potential antiparasitic activity of less conventional resources, represented by different agro-industrial by-products (AIBPs). This review presents in vitro and in vivo results obtained with a range of tannin-containing AIBPs of various geographical and botanical origins, namely AIBP of nuts, temperate and tropical barks, carob, coffee and cocoa. They tend to confirm the "proof of concept" for their antiparasitic effects and also for other aspects of ruminant production in an agro-ecological context. Socio-economic aspects of the exploitation of such non-conventional resources are also discussed as potential models of the circular economy, by using waste. The different modes of use of these resources are presented in this review, as well as strengths, weaknesses, opportunities, and threats (SWOT) analyses to illustrate the advantages and limitations of on-farm use.
\end{abstract}

Key words: Plant secondary metabolites, Plant specialised metabolites, Tannins, Anthelmintic resistance, Gastrointestinal nematodes, Circular economy.

\begin{abstract}
Résumé - Utilisation de sous-produits agro-industriels contenant des tanins pour le contrôle intégré des nématodes gastro-intestinaux chez les ruminants. Plusieurs études antérieures ont illustré le fait que des légumineuses bioactives contenant des tannins condensés peuvent représenter une des alternatives à intégrer avec d'autres options pour une maitrise durable des nématodes gastro-intestinaux en réponse au développement constant et à l'expansion continue à l'échelle mondiale des résistances aux anthelminthiques de synthèse. Des recherches plus récentes se sont intéressées au potentiel d'application de ressources moins conventionnelles que représentent des coproduits agroindustriels (CPAI). Cette revue vise à présenter des résultats in vitro et in vivo obtenus avec une
\end{abstract}

*Corresponding author: herve. hoste@envt. fr

\section{COMBCR Special Issue - Combatting Anthelmintic resistance in ruminants Invited Editors: Johannes Charlier, Hervé Hoste, and Smaragda Sotiraki}


gamme de CPAI d'origines géographiques et botaniques diversifiées (coproduits de l'industrie des noix, du bois (en régions tempérées et tropicales), du caroubier, du café et du cacao). Ces résultats ont confirmé la preuve de concept pour les effets antiparasitaires, et aussi pour d'autres volets de la production des ruminants dans un contexte agro écologique de l'élevage. Par ailleurs, les aspects socio-économiques d'exploitation de ces ressources, considérées jusqu'à présent comme des déchets, dans un modèle de circuits courts sont aussi évoqués. Les avantages et inconvénients des différentes modalités d'exploitation des CPAI sont aussi discutés dans le cadre d'une analyse SWOT.

\section{Context}

Worldwide, infection of the gastrointestinal tract of ruminants with parasitic nematodes remains the main challenge associated with outdoor production. This is because of the consequences on animal health and welfare of these helminth infections and also because of their major impact on productivity and on the economy of farms [22, 23]. The efficient control of these infections is essential to improve livestock health and production and consequently rural livelihoods.

For several decades, the control of these parasitic infections has mainly relied on the repeated use of chemical anthelmintics (AHs) provided by pharmaceutical companies. However, the accelerating development of resistance to AHs in worm populations and the extent of the phenomenon, including the rise of multi-resistant isolates, has been reported worldwide [102], see also STAR IDAZ website https://www.star-idaz.net/prioritytopic/helminths-including-anthelmintic-resistance/ and the website of the COST action COMBAR https://www.combar-ca.eu/). Moreover, the development of resistance to AHs and other chemical drugs appears to be an inevitable process [118]. These different facts underline the need for a change in the mode of control of Gastrointestinal nematodes (GIN), instead of exclusive reliance on synthetic AH drugs. The general objective is nowadays to promote a more integrated approach, based on a combination of options which correspond to different principles and modes of action [112]. This more sustainable approach, which was foreseen even more than 20 years ago [110], is now generally agreed among parasitologists to be essential [22, 78].

Within the "basket of options" to control GIN [55], research into bioactive plants with $\mathrm{AH}$ properties has received strong impetus since the end of the 1990s. These antiparasitic activities have been associated with the presence of a range of plant secondary metabolites (= plant specialised metabolites) (PSMs) which are present in a large number of botanical families. For example, the potential use of chicory (Cichorium intybus) for its $\mathrm{AH}$ properties has been related to the presence of sesquiterpene lactones [92], while proteinases have been considered responsible for anthelmintic activity in several tropical plants [109]. Moreover, some fodder species of the Legume family (Fabaceae) containing condensed tannins (CTs) have been used as models to explore the $\mathrm{AH}$ effects of this particular class of PSM [45], e.g. sulla (Hedysarum coronarium), big trefoil and bird's-foot trefoil (Lotus pedunculatus and L. corniculatus), sainfoin (Onobrychis viciifolia) and sericea lespedeza (Lespedeza cuneata). Data on evaluation of PSMs against parasites have generally relied first on a range of in vitro assays, followed by studies performed in animals, either in controlled experimental conditions or in controlled systematic trials. A last step is to confirm the possible application by studies based on on-farm conditions [47].

The main conclusions from these studies in CT-containing legumes, working hypotheses on the mode of action, and bottlenecks or hurdles identified from the various experimental studies are:

(i) the presence of CT-containing forages in the ruminant diet can affect the dynamics of GIN infections by disrupting the biology of different key stages of the GIN life cycle;

(ii) the antiparasitic activity has been associated with the presence of CTs and also other related polyphenols, such as flavonoids, that are biosynthetic precursors of CTs;

(iii) in regard to the potential application of such bioactive resources in farming conditions, the results have led to propose the concept of "nutraceuticals". These are resources combining nutritional and health values for ruminants [47]. In contrast to synthetic $\mathrm{AH}$ drugs, nutraceutical fodders are not imposed (administered by force) but proposed to the animals. Therefore, the $\mathrm{AH}$ effects of such CT-containing resources used as nutraceuticals depend first on voluntary feed intake (VFI) by sheep, goats or cattle. Torres Acosta and his group [112] have proposed criteria to define nutraceuticals with antiparasitic activity;

(iv) based on the "direct" hypothesis, relying on pharmacological-like effects of CT on the different key stages of GIN [45], data have been obtained to suggest that the in vivo $\mathrm{AH}$ effects depend on both a sufficient length of time to distribute the bioactive resources to animals, as well as a sufficient level (threshold) of polyphenols in the ruminants' diet to expose worms to the bioactive compounds in the relevant digestive organs.

The identification of a main role of CTs and related polyphenols in the $\mathrm{AH}$ activity of legume forages has stimulated further exploration of the potential activity of other resources [46]. In particular, the worldwide coexistence of GIN in livestock and of polyphenol-containing legumes led to further studies to examine the value of a range of tropical plants, especially of the Fabaceae family, under a wide range of environments and management conditions. Secondly, the presence of polyphenolic compounds in a wide range of agro-industrial by-products (AIBPs) has stimulated interest in the potential antiparasitic activity of these resources.

The early impetus to exploit different AIBPs has been influenced by their potential nutritional value, and has focused on by-products of the food and wine industries, e.g. wine grape 


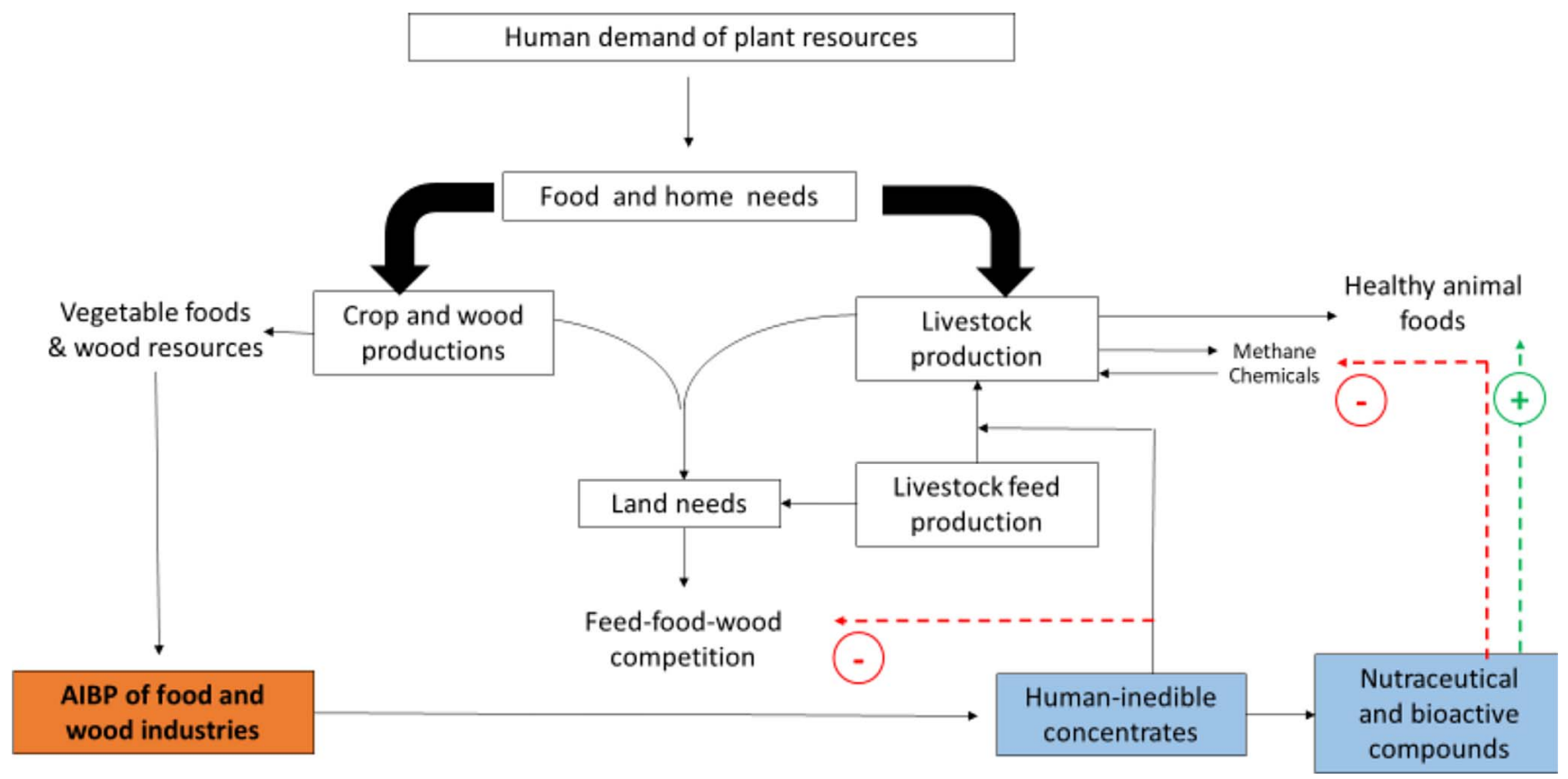

Figure 1. Beneficial role of the use of agro-industrial by-products (AIBPs) in animal production. A framework to develop the circular economy, including the potential effects on animal health through the use of nutraceuticals (Adapted from [26]).

pomace, citrus pulps, and oil cakes. This first valorisation has been identified since the 1960's and has led to long-term use of AIBPs as feeding resources in different livestock species, including ruminants. More recently, there has been renewed interest to exploit these AIBPs because of the presence of bioactive components. The PSMs contained in AIBPs can help to address several novel objectives. For instance, phasing-out of growth promoters and antibiotics, and a move towards the concept of agroecology in order to achieve more sustainable management of agriculture and livestock breeding, according to different criteria in a holistic framework, as illustrated in Figure 1.

The general objective of this review is to present a critical overview of the potential application of AIBPs by focusing on tannin-containing resources and on their combined nutritional and health-promoting value as nutraceuticals, specifically with potential AH activities against GIN of ruminants. Instead of being exhaustive, this review will focus on a few selected models of AIBPs obtained from different agro-industries, in order to illustrate the diversity of AIBPs, which can be exploited because of their bioactivity across a wide range of environmental conditions. These also exemplify a model of the circular economy to exploit industrial waste, addressing economic and social issues and enhancing the sustainability of food production [26]. For each selected example of an AIBP, data will be provided to illustrate:

(i) the geographical, historical, and economic context of each type of production,

(ii) the potential AH activity and other antiparasitic effects (e.g. on other infections),

(iii) a critical evaluation of the phytochemical compounds whose role is suspected to underpin the AH effects, (iv) the different possibilities of utilising these AIBPs in current livestock production systems.

Furthermore, besides their antiparasitic effects, utilising the bioactivity of AIBPs in an agro-ecological context could add wider value to ruminant production and nutrition. These are also discussed, as well as potential further implementation in other livestock species (pigs, horses, poultry, and rabbits) and parasites. An analysis of the strengths, weaknesses, opportunities and threats (SWOT) surrounding the application of AIBPs in this context is also presented, against a wide range of criteria (e.g. availability, cost, competition with other industries, and other possible uses in animal health) for the AIBPs presented in this review.

\section{AlBPs useful for parasite control Temperate nuts: chestnuts and hazelnuts}

Nuts are fruits composed of an edible seed (called "almonds") and of hard shells which are non-edible and which correspond to the pericarps composed of three separate layers. Hazelnut (Corylus avellana, Betulaceae) and chestnut (Castanea sativa, Fabaceae) form the basis of important industries in southern Europe, China and Central Asia, the USA (for hazelnuts) and South America (for chestnuts). In both cases, the almonds are of high value for human consumption. However, the hard shell, which is composed of the endocarp-meso and exocarps, are usually considered waste, although they might represent almost 15-20\% of the whole weight of the fruit (e.g. for chestnut). The by-product (BP) of hazelnuts consists only of the endocarps, while for chestnuts, the BP constitutes a mixture of endocarps and mesocarps. 
Leaves of nut-producing and other trees also have potential uses. The presence of tannins in the barks of different trees (e.g. oak trees, chestnut trees) of the Fagaceae family have been empirically exploited in Europe since early ancient times in tanneries for leather production. In addition, a study based on different in vitro assays [88] confirmed the potential AH effects of extracts of leaves of hazelnut and oak (Quercus robur) on three major GIN genera of ruminants. These early results, combined with the presence of condensed tannins in both hazelnuts and chestnut peels, helped to explain the bioactivity of the BP of nut peels and their potential antiparasitic agents.

For hazelnut and chestnut, several in vitro studies have indicated potential benefits of including the BP in ruminant feed, and for future use as nutraceuticals [47]. Various in vitro assays have been performed, with Haemonchus contortus the most common GIN model species used [66], although effects on the intestinal species Trichostrongylus colubriformis have also been examined [9, 30]. Moreover, the hypothesis of a suspected major role of tannins and other polyphenols in observed antiparasitic effects was confirmed by the use of tannin inhibitors such as polyethylene glycol (PEG) or polyvinylpolypyrrolidone (PVPP) [9, 66, 88].

In some of these in vitro studies, sainfoin extracts were included in the experimental design, thus allowing a comparison of values of half-maximal inhibitory concentrations $\left(\mathrm{IC}_{50}\right)$ with hazelnut $[13,98]$ and chestnut extracts. Overall, lower $\mathrm{IC}_{50}$ values for the $\mathrm{BP}$ of nuts were obtained, suggesting higher $\mathrm{AH}$ activity than sainfoin, which is used as a reference of a tanniferous legume [47]. For example, the $\mathrm{IC}_{50}$ obtained with an acetone/aqueous extract defined on larval exsheathment inhibition ranged from 47 to $104 \mu \mathrm{g} / \mathrm{mL}$ for hazelnut and 99-399 $\mu \mathrm{g} / \mathrm{mL}$ for sainfoin [13]. Similar values of halfmaximal effective concentration $\left(\mathrm{EC}_{50}\right)$ were obtained with chestnut extracts (31-96 $\mu \mathrm{g} / \mathrm{mL})$ [30]. These studies also explored the variability in AH efficacy for both hazelnut and chestnut depending on a range of factors, namely the environmental conditions of production (e.g. chestnuts grown in France or Chile), genetic factors (cultivars), and in the case of chestnuts, different technological processes applied to isolate the almonds (= fruits/seeds).

For both types of $\mathrm{BP}, \mathrm{AH}$ properties have been confirmed in vivo. When hazelnut peels were distributed to goats experimentally infected with $H$. contortus and $T$. colubriformis, a significant reduction of $>50 \%$ in nematode faecal egg count (FEC) was observed, which was related to a decrease in the fecundity of female Haemonchus. A non-significant reduction of $45 \%$ in T. colubriformis populations was also found [34]. In a second step, the distribution of hazelnut peels in goats targeting the early phase of infection led to decreases of $48 \%$ for $H$. contortus and $42 \%$ for $T$. colubriformis in the establishment of third stage larvae of each species. One of the findings of the study was the ability of goats to voluntarily ingest up to $350 \mathrm{~g}$ of hazelnut peels per day, following a period of adaptation. According to the same design, similar results (decrease by $40 \%$ in FEC) were obtained in lambs with daily consumption of peels limited to $140 \mathrm{~g}$ [34].

The potential benefits of adding hazelnut peels to the diets of lambs infected with $H$. contortus was confirmed in another study, in which adding hazelnut peels to sainfoin pellets obtained significant decreases of $50-60 \%$ in egg excretion, but without any difference in worm numbers [40]. However, other studies [98] examining the $\mathrm{AH}$ consequences of prolonged feeding of hazelnut peels to infected lambs did not provoke any significant changes in egg excretion by Haemonchus, and only a small significant decrease in egg excretion and female fecundity for $T$. colubriformis. The value of combining tannins from two different resources was again illustrated in a recent study, which examined the AH effects when incorporating chestnut peels in sainfoin pellets offered to lambs infected with both abomasal and intestinal species [68]. With only tannins from chestnuts, the effects on egg excretion were non-significant. However, the combination of sainfoin and chestnut BP was associated with significant effects on the parasites and favourable consequences for host resilience, i.e. decreased anaemia.

The availability of tannins from the AIBP of chestnuts and hazelnuts has also been investigated, to better understand the mode of action of tannins on different GIN stages and/or species. Again, comparison with data obtained with CT containing legumes (e.g. sainfoin) is informative. The hypothesis of a direct mode of action of tannins against nematodes has been confirmed by results of several in vitro studies, including examination of structural changes based on observations using scanning and transmission electron microscopy [44, 45]. Results showed that changes occurred in the cuticle of adult worms, which were not seen after exposure to sainfoin extracts [69, 70].

Several studies have provided information not only on the content of tannins and other polyphenols, but also on the qualitative characterisation of both chestnut and hazelnut peels, namely the procyanidin to prodelphinidin ratio (PC/PD), the mean degree of polymerisation $(\mathrm{mDP})$ and the cis/trans ratio [98]. Because some of these studies also included data on sainfoin, and other CT-containing fodders, and an evaluation of the AH effects, the results helped to address basic questions on the structure-AH activity relationship, and to analyse factors modulating the antiparasitic effects [79]. Comparison between a fodder (sainfoin) and hazelnut peel has also been performed to examine the distribution and fate of tannins from each plant in the sheep digestive tract [97].

Phytochemical analyses using ultra performance liquid chromatography-tandem mass spectrometry (UPLC-MS/MS) have been performed to characterise a variety of chestnut BPs of different geographical origins and following different technological processes (direct heat versus microwave). Results showed the presence of CT and both ellagic and gallic acids, suggesting the co-presence of some hydrolysable tannins. The characterisation of CT on eight samples suggested generally higher PD- $\%$ than PC- $\%$, with PD content ranging from $46 \%$ to $84 \%$. The $\mathrm{mDP}$ was 14.8 , and the $\mathrm{CT}$ content ranged from 1.01 to $4.01 \mathrm{~g}$ per $100 \mathrm{~g}$ of dry matter (DM) (JP Salminen, personal communication).

For hazelnut peels, the main PSMs have been identified as being oligomeric and polymeric CT. Based on a method of thiolytic degradation coupled with high performance liquid chromatography (HPLC), the content of tannins in hazelnut peels was $6.27 \mathrm{~g}$ of proanthocyanindin per $100 \mathrm{~g} \mathrm{DM}$ (compared with 1.71 in sainfoin). The CT of hazelnut peels consisted 
mostly of procyanidins (PC/PD ratio 72/28) with $\mathrm{mDP}$ of 13.3 [97]. Moreover, the CT of hazelnut endocarps was also characterised by a high level of galloylated flavonoids.

Compared with tannin containing legume fodders like sainfoin (Onobrychis viciifolia) or sericea lespedeza (Lespedeza cuneata), knowledge of the properties of hazelnut and chestnut $\mathrm{BP}$ remain limited. However, they have confirmed the potential of tannin-containing AIBP of nuts to aid in GIN control. The early results from chestnuts and hazelnuts have led to further studies using BP from other nut industries like shea nut (Vitellaria paradoxa, Sapotaceae) [100], peanut (Arachis hypogaea, Fabaceae) [62] and walnut (Juglans spp., Juglandaceae).

\section{Mediterranean carob pods}

Carob (Ceratonia siliqua) is a leguminous tree that is traditionally found in the Mediterranean area. Spain is the main producer and exporter, followed by Italy, Morocco, Portugal, Greece, Turkey and Cyprus. Cultivation also occurs in areas with similar climates, like the South-East USA, and parts of Australia and South Africa [10]. Carob fruit is a brown pod whose main raw material used in industry consists of the pulp (90\% of pod weight) and the seeds. Carob pulp has a high sugar content $(48-56 \%)$, and relatively low fat $(0.4-0.8 \%)$ and protein $(3-4 \%)$ [10, 67].

Carob trees have been used for centuries as a cheap source of both human and animal nutrition. Since they are mostly cultivated in dry areas with low rainfall, they require little attention and live up to 150 years $[42,67,99]$. Nowadays, carobs are used in food, pharmaceutical and cosmetic industries [54, 114] and in the fast-growing health food industry, since carob products have important nutritional and medicinal properties for humans $[24,106]$. The BP of carob (CaBP) described herein concern the seedless carob fruit, called "pulp", which is crushed and traditionally added to animal feed.

Carob tree parts (pods, seeds, germs, leaves and tree barks) are substantial sources of polyphenolic compounds, such as gallic acid, catechin, epicatechin, epicatechin gallate, epigallocatechin, epigallocatechin gallate, myricetin, and quercetin and their derivatives. Carob pod contains a higher amount of polyphenols in comparison to seed or germ [107]. Although a higher level of condensed than hydrolysable tannins is present, their reported concentration varies. Bravo et al. (1994) [14] and Batlle and Tous (1997) [10] reported concentrations of 16-20\% w/w DM of CT in ripe carob pods. This has been debated by Priolo et al. $(2000,2002)$ [94, 95], who claimed that the pods have low content of CT, but exceptionally high biological activity. Silanikove et al. (2006) [106] demonstrated that the yield of CT is considerably affected by the extraction method applied (from $5.0 \mathrm{~g} / 100 \mathrm{~g} \mathrm{DW}$ with acidic methanol to $17.2 \%$ with urea-buffer solution), suggesting that carob pods are a rich source of CT. Similarly, Saratsi et al. (2020) [103] reported $5.84 \mathrm{~g} \mathrm{CT} / 100 \mathrm{~g}$ DW with acetone-HCl/butanol extraction method and 7.20 g CT/100 g DW based on the thiolysis method.

There is only one published in vitro study testing the $\mathrm{AH}$ efficacy of carob pods. In this study, the larval exsheathment inhibition assay (LEIA) was used to test the effect of $\mathrm{CaBP}$ against $H$. contortus and $T$. colubriformis larvae. The results showed no effect against $H$. contortus, but a noteworthy effect against $T$. colubriformis. Specifically, when larvae were exposed to an extract concentration of $1200 \mu \mathrm{g} / \mathrm{mL}$, only $40.57 \%$ of L3 of T. colubriformis exsheathed, yielding an estimated $\mathrm{EC}_{50}$-value of $1163.85 \mu \mathrm{g} / \mathrm{mL}$ [104].

Confirmation of the $\mathrm{AH}$ properties of $\mathrm{CaBP}$ was then obtained in vivo. $\mathrm{CaBP}$ meal was incorporated into the ration of sheep experimentally infected with $H$. contortus and T. colubriformis, and a significant reduction of $>39 \%$ in FEC was observed, which was related mainly to a decrease in egg output of females and to a lesser degree in the number of adult parasites. Moreover, the hypothesis of a suspected major role of tannins in these antiparasitic effects was confirmed by use of inhibitors such as PEG [103].

Particularly for $H$. contortus, it appears that fecundity is only affected when the worms are exposed to CT during maturation, and not when they are already mature adults. On the other hand, when CaBP was consumed for two weeks by animals in which adult worm populations were already established and patent, the main finding was a significant decrease in $H$. contortus worm counts. Overall, the current study adds further support to the observation that most of the CT effect is related to abomasal parasites, and not as much to small intestinal parasites [103]. In one of the above-mentioned trials, a combination of a fodder (sainfoin) and a BP (CaBP) was offered to animals to investigate whether different tannin sources can act synergistically. No synergistic effect was recorded [103]. In this study, the main tannins of carob were CT whose PC/PD ratio approximates to 3.3/96.7, and an $\mathrm{mDP}$ of 31.2 associated with a $\%$ galloylation close to 41.1. However, like for tannin-containing legumes, agroenvironmental conditions have a strong effect on compositional traits, including condensed tannin composition [56].

\section{Bark from temperate trees}

The tree industry is large in northern European countries, within the temperate climate zone. In Norway, Sweden and Finland, large amounts of coniferous trees (mainly Scots pine, Pinus sylvestris, and Norway spruce, Picea abies) and smaller amounts of white birch (Betula pubescens) are harvested annually, mainly for use as building material and pulp for paper production. This results in large amounts of bark as an unexploited by-product, of which a major part $(60 \%)$ is used for bioenergy. In 2019, Norway alone had an estimated production of 0.22 million tonnes of wet bark from pine and spruce [96]. Denmark also utilises various fast-growing deciduous trees for bioenergy (e.g. willow, Salix spp., hazel, Corylus spp., and poplar, Populus spp.), and leaves and branches of these species have been used for centuries as winter feed for livestock [57].

Seen in a historical perspective, several tree species have been used as medicine in temperate Europe. Willow bark, various concoctions of pine (bark, needles, and buds) and birch leaves were used for treating urinary tract infections, upper respiratory infections, or mild rheumatism [101]. Similarly, helminth infections of humans or livestock, mainly horses, were traditionally treated with bark or other products of various tree species, e.g. P. abies, P. sylvestris and juniper (Juniperus communis), Salix spp., and B. pubescens [120]. Willow bark is a source of salicin, a potent anti-inflammatory [63]. 
The bark of several coniferous species and some deciduous trees growing in the temperate climate zone is rich in CT, predominantly procyanidins (PC) of short to medium $\mathrm{mDP}$. For example, extracts of $P$. sylvestris were reported to contain $3-8 \%$ CT comprised of $100 \%$ PC with an mDP of $6-7$, and P. abies contained 1-7\% CT comprised of $80-100 \%$ PC with an mDP of 7-8 [7]. Similarly, extracts of willow bark contained $14.6 \%$ CT with $100 \%$ PC and mDP of 4.6 [101]. Other studies have indicated a higher proportion of PD (up to $50 \%$ ) in various parts of deciduous trees, e.g. hazel, birch, walnut, and catkins and twigs of willow [33].

In general, high levels of anti-parasitic effects in vitro from acetone-water extracts of plants have been associated with both a high proportion of $\mathrm{PD}$ and a high $\mathrm{mDP}$ of the $\mathrm{CT}$ within the extract [33, 98]. Similarly, other biological activities of CT, such as in vitro immune-modulating activity, is stronger in $\mathrm{CT}$ with an $\mathrm{mDP}>6$ compared to $\mathrm{CT}$ with lower $\mathrm{mDP}$ [121]. However, several extracts from tree species with high PC levels still had marked anti-parasitic effects [33]. This offers large potential also for the woody species. Consistent with this, in vitro activity against ruminant nematodes has been demonstrated for extracts of different parts of a range of tree species, including Betula, Castanea, Corylus, Pinus, Quercus, Salix and Tilia spp. [33, 76, 88, 98]; reviewed in reference [48]. More recently, it was demonstrated that acetone: water extracts of bark from $P$. abies, $P$. sylvestris, and B. pubescens inhibited egg hatching of Teladorsagia circumcincta by 85-100\% [7].

Promising in vivo results have been obtained in trials with Salix spp. in infected sheep either fed chopped willow branches with leaves [80] or browsing on young willow shoots [36, 82], resulting in a high daily intake of CT. Reduced dag scores (i.e. less soiling of hindquarters) have been found consistently, while reductions in FEC have been observed, although moderate and variable. Examinations of worm burdens post mortem have shown reduced levels of abomasal nematodes, particularly $H$. contortus, and small intestinal species, e.g. Cooperia spp. [80], or of small intestinal nematodes only [36].

Utilisation of the bark of coniferous species in livestock diets is likely to be increasingly relevant, given its high accessibility. Min et al. (2015) [75] found that feeding pine bark powder in the diet (3.2\% CT of diet DM) to goats experimentally infected with $H$. contortus reduced worm burdens by $68 \%$ and FEC up to $30 \%$, without negative impacts on body weight or condition. Furthermore, Wright (2015) [123] found that $H$. contortus infected goats had a lower FEC and worm burden when fed a CT-rich diet consisting of a mixture of loblolly pine (P. taeda; native to the Southern USA), bark powder and Lespedeza cuneata pellets, compared to separate pine bark and L. cuneata diets and a control group fed a diet lacking in CT. These results suggest a synergistic effect between components in P. taeda bark and L. cuneata when fed in a mixed diet. Moreover, CT in the diet enhanced the immune functions of the host.

Bark extracts have also shown activity against parasites other than nematodes. Teichmann et al. (2016) [111] found that bark extracts from Salix spp. inhibited Cryptosporidium parvum in cell cultures. More recently, it has been shown that wateracetone extracts of pine bark ( $P$. sylvestris) may inhibit C. parvum growth in cell culture with an $\mathrm{IC}_{50}$ of $25.4 \mu \mathrm{g}$
$\mathrm{CT} / \mathrm{mL}$ [12], thus supporting an earlier trial finding reductions in the faecal oocyst counts of $C$. parvum-infected mice offered a commercial pine bark ( $P$. pinaster) product [52]. Further, a water extract of $P$. radiata inhibited the sporulation of Eimeria coccidia by up to $84 \%$ [77]. Anti-cestode effects of pine bark have also been demonstrated in rodents, as Dhakal et al. (2015) [35] found inhibition of Hymenolepis diminuta cysticercoid excystation in the same dose-dependent manner as the registered pharmaceutical drug praziquantel. They concluded that PC-rich CT inhibited excystation more effectively than PD-rich $\mathrm{CT}$, which is only partially supported by the above for nematodes. Impacts of bark BP on parasites other than nematodes have yet to be explored in vivo in ruminants.

In brief, it seems likely that there is scope for development of anti-parasitic products from the readily available bark of coniferous trees. Despite the current paradigm of PD-rich extracts being the most effective against nematodes, extracts rich in PC may still hold promise. In other parasitic infections, PC-rich extracts may even prove to be superior. However, as bark from the wood industry, particularly conifers, will in most cases have low digestibility and not be practical directly as livestock feed, extraction is necessary in order to obtain a usable product. Extraction with organic solvents, as applied in most experimental studies, is impractical and expensive. Water extraction is most likely the only way forward, as already practised in commercial production of CT from Acacia spp. in the tropics [84]. This will probably result in a different composition of CT as well as substantially lower yields. Contamination of bark products with soil and sand is also a major challenge [108]. It is important for future research to address these issues in order to make bark products a viable option for parasite prevention in livestock.

\section{Bark and wood from tropical and subtropical regions}

Global harvest and the production of wood products, mainly wood panels, sawn wood, paper, and paperboard, have risen markedly in the last six decades, and projections show that this trend will continue to increase [51]. Tannins are some of the main by-products derived from wood production globally, which can lead to significant added value through use in the production of leather, oil, wine, beer, ceramic production, and plastics and adhesives; as well as wastewater treatment and other applications [31, 93]. Some $90 \%$ of global tannin output consists of CT, and annual production reaches up to 200000 tons. The tree species used for tannin production vary regionally, being mainly black wattle (Acacia mearnsii) in Brazil, South Africa, India, and other tropical countries, and Quebracho (Schinopsis spp.) in South America.

Species of Acacia are responsible for $9.7 \%$ of tropical and subtropical tree plantations. Black wattle (A. mearnsii) is the main species grown commercially on an international scale $[19,117]$. Wattle tannin is commercially produced by extraction from A. mearnsii bark using hot water, with $\mathrm{CT}$ as the major component [83]. Ease of extraction and high CT yield makes A. mearnsii bark extract an excellent candidate to control GIN in livestock, including ruminants. Its effectiveness in vitro has been shown against $H$. contortus, Trichostrongylus 
vitrinus, and Teladorsagia circumcincta using the larval feeding inhibition assay [72]. The in vitro effect of extract of A. mearnsii bark on egg hatch and larval migration is, however, low, with $\mathrm{IC}_{50}$ of 2.8 and $12.4 \mathrm{mg} / \mathrm{mL}$, respectively [124]. Ultrastructural changes in the cuticle of $H$. contortus adults have been shown after exposure to tannins [125].

Intake of A. mearnsii bark in feed by sheep and goats reduced the GIN FEC $[18,27,73]$. Also, it reduced egg viability and consequently the quantity of L3 from eggs collected from animals fed with A. mearnsii bark extract [74]. These results indicate the potential of feeding such tannins to reduce infective larvae on the pasture and, consequently, animal reinfection. Also, numbers of T. colubriformis and Cooperia spp. adults were reduced in sheep that received A. mearnsii bark extracts [18], but they did not reduce $H$. contortus, T. colubriformis, and Oesophagostomum columbianum adult worms in goats [27]. It has also been shown that the use of A. mearnsii bark did not alter blood parameters or carcass measurements of sheep and goats naturally or experimentally infected with nematodes [18, 27, 73, 74].

Supplementary feeding of CT from A. mearnsii has been shown to reduce methane emission in cows and sheep $[2,3,32]$. However, this reduction was not observed in sheep infected with $T$. colubriformis and $H$. contortus [60]. Acacia mearnsii supplementation also affected the structure of the ruminal microbial community, modulating important microbe groups affected by GIN infection in lambs [25]. Bioactivity to suppress methane production, if carried out in the field, could increase the beneficial effects of feed intake of $A$. mearnsii on animal production.

Quebracho is one of the most important bark extracts used in the tannin industry, mainly in Latin America, where it comes from barks of different trees of the genus Schinopsis [50]. The CT concentration ranges from $35 \%$ to $73 \%$ depending on quebracho extracts $[5,6,8,61]$. The $\mathrm{CT}$ of quebracho are usually described as profisetinidins. The high production and concentration of CT make quebracho extracts an excellent candidate to use in the field as nutraceuticals for ruminants.

Quebracho extracts have shown activity against H. contortus, T. circumcincta, and Tr. vitrinus using larval migration and larval development assays [5, 6, 43]. Results in vivo showed efficacy in sheep infected by $H$. contortus, T. colubriformis, and Nematodirus battus. However, trials are contradictory in the apparent mechanism of action, with reduction of egg output being the more substantial result [5, 6, 71]. In goats, the effect of administration of quebracho extracts on $T$. colubriformis and $T$. circumcincta egg excretion was shown, but not on $H$. contortus [87, 89, 90]. Quebracho supplementation also reduced the excretion of Eimeria oocysts in lambs and goat kids, but did not reduce clinical signs of coccidiosis [1]. These results show the importance of more studies with other parasites as potential targets of CT. Evaluation of possible impacts on specific and non-specific immunological responses is an important area for future research.

Tannins from the bark of tropical trees have therefore been shown to have potential use to control GIN in ruminants, and should be considered for use as nutraceuticals to improve livestock production. It is essential to highlight that several factors could influence outcomes of CT feed supplementation from these and other sources, especially dosage, and nematode and host species. The cost of CT sources in different regions should also be considered before planning the use of these compounds as nutraceuticals in livestock. The use of by-products with a high concentration of CT has the potential to make livestock production more sustainable, given the low residues in meat and milk and low environmental impact.

\section{Tropical by-products other than bark}

Several polyphenol-rich materials from temperate regions have been proposed, aiming to achieve added value materials currently considered waste that needs to be discarded in a way that does not affect the environment. A similar approach has been proposed for tropical regions. However, this search has also been prompted by a recent discovery: an H. contortus isolate from Mexico showing lower susceptibility to polyphenol-rich acetone: water extracts produced from leaves of plants commonly ingested by local sheep or goats [16, 21, 115]. These authors proposed that the $H$. contortus isolates obtained from animals browsing the tropical forest of Mexico showed some level of adaptation to plant polyphenols, possibly due to the constant exposure of the local GIN to the polyphenol-rich vegetation consumed by the hosts browsing this area.

This finding stimulated the quest for polyphenol-rich plant materials that can be used as ruminant feeds, but which are not included in the normal diet of grazing ruminants. The search began by testing polyphenol-rich plant materials that are not part of the normal diet of ruminants, such as mangrove leaves and locally available AIBPs such as Coffea arabica spent coffee grounds (SCG) or Theobroma cacao pod husks and leaves. These materials were confronted with a second criterion: the chemical composition of the tested AIBPs should be suitable for ruminant nutrition. A third criterion consisted of the acceptable consumption of the respective AIBPs by ruminants. These three criteria were met both for the SCG and the T. cacao leaves [58, 85, 86]; García-Ceballos et al., 2018 [37, 64].

\section{Evidence of anthelmintic activity of spent coffee grounds (SCG)}

The in vitro evidence of $\mathrm{AH}$ activity against $H$. contortus eggs and L3 larvae of different SCG varieties is shown in Table 1. Different tests showed activity using the egg hatch test, with promising results [58], although poor results were found for eggs in other studies [115]. The larval exsheathment inhibition test showed variation in the activity against L3 when using acetone: water extracts obtained from different SCG varieties from Mexico. The in vitro activity also varied when using different $H$. contortus isolates, with stronger activity observed for parasites of French origin, and lower activity for parasites from Yucatán, Mexico [116].

The in vivo evidence of AH activity against $H$. contortus or natural GIN infections in sheep and goats consuming different quantities of SCG is shown in Table 2. From the generated evidence, it was possible to confirm that sheep and goats are able to consume a considerable quantity of SCG mixed in the concentrate feed used by these animals (from $10 \%$ to $40 \%$ of 
Table 1. In vitro anthelmintic activity of different varieties of spent coffee ground (SCG) acetone: water extracts against $H$. contortus eggs and L3 of different origins. The condensed tannin content of each extract (catechin equivalent) is also included, as well as the confirmation of the role of polyphenols in the in vitro activity by using the tannin inhibitor polyvinylpolypyrrolidone.

\begin{tabular}{|c|c|c|c|c|c|c|c|}
\hline $\begin{array}{l}\text { Varieties of Mexican } \\
\text { Coffea arabica }\end{array}$ & In vitro test & $\begin{array}{c}\text { Haemonchus } \\
\text { contortus isolate }\end{array}$ & $\begin{array}{c}\text { Condensed } \\
\text { tannin } \\
\text { content }(\%)^{*}\end{array}$ & $\begin{array}{l}\text { AH activity } \\
\text { (\% inhibition) }\end{array}$ & $\begin{array}{l}\text { Effective concentration } \\
50 \% \text { ( } 95 \% \text { confidence } \\
\text { interval) in } \mu \mathrm{g} / \mathrm{mL}\end{array}$ & $\begin{array}{l}\text { Confirmed } \\
\text { role of } \\
\text { polyphenols }\end{array}$ & Reference \\
\hline Tazza $^{\circledR}$ Veracruz & EHT at $2400 \mu \mathrm{g} / \mathrm{mL}$ & CENID-INIFAP & 5.58 & 91.6 & & Not tested & [58] \\
\hline Tazza $^{\circledR}$ Oaxaca & & & 6.33 & 53.7 & & & \\
\hline Tazza ${ }^{\circledR}$ Chiapas & & & 5.89 & 91.6 & & & \\
\hline Garat $^{\circledR}$ & & & 2.02 & 92.8 & & & \\
\hline Garat ${ }^{\circledR}$ Décaf & & & 6.20 & 94.9 & & & \\
\hline Inter ${ }^{\circledR}$ Décaf & & & 1.00 & 87.3 & & & \\
\hline Starbucks ${ }^{\circledR}$ SG & & & 2.66 & 92.4 & & & \\
\hline Starbucks ${ }^{\circledR} \mathrm{CS}$ & & & 2.28 & 57.7 & & & \\
\hline Garat $^{\circledR}$ & EHT & CENID-INIFAP & 2.02 & No activity & & PVPP & [115] \\
\hline \multirow[t]{5}{*}{ Garat $^{(B)}$} & LEIT at $1200 \mu \mathrm{g} / \mathrm{mL}$ & FESC-UNAM & 2.02 & 93.9 & & PVPP & {$[116]$} \\
\hline & & CENID-INIFAP & & 98.0 & & & \\
\hline & & Poxila & & 86.0 & & & \\
\hline & & INRA & & 100.0 & & & \\
\hline & & Sheep France & & 100.0 & & & \\
\hline Starbucks ${ }^{\circledR} \mathrm{CS}$ & LEIT & FESC-UNAM & 2.28 & & $266.56(221.86-309.91)$ & PVPP & [29] \\
\hline Starbucks ${ }^{\circledR}$ SG & & & 2.66 & & $176.1(108.55-239.99)$ & & \\
\hline Starbucks ${ }^{\circledR} \mathrm{CS}$ & LEIT & Paraiso & 2.28 & & $699.28(571.31-871.04)$ & PVPP & [85] \\
\hline Starbucks ${ }^{\circledR}$ SG & & & 2.66 & & $746.11(471.35-879.44)$ & & \\
\hline
\end{tabular}

* Catechin equivalent.

Table 2. In vivo anthelmintic activity against gastrointestinal nematode infections using different types of spent coffee ground (SCG) mixed within the feed of goats and sheep. The condensed tannin content of each extract (catechin equivalent) is also included, as well as the confirmation of the role of polyphenols in the in vivo activity using polyethylene glycol.

\begin{tabular}{|c|c|c|c|c|c|c|c|}
\hline $\begin{array}{l}\text { Varieties of } \\
\text { Mexican Coffea } \\
\text { arabica }\end{array}$ & $\begin{array}{l}\text { Animal } \\
\text { species }\end{array}$ & $\begin{array}{l}\text { Gastrointestinal } \\
\text { nematode } \\
\text { infection }\end{array}$ & $\begin{array}{c}\text { Condensed } \\
\text { tannin content } \\
\text { of SCG }\end{array}$ & $\begin{array}{l}\text { Inclusion } \\
\text { level of } \\
\text { SCG }\end{array}$ & Activity & $\begin{array}{l}\text { Confirmed } \\
\text { role of } \\
\text { polyphenols }\end{array}$ & Reference \\
\hline Garat $^{(B)}$ & Goats & Natural mixed infection & $2.69 \%$ & $\begin{array}{c}15 \% \\
30 \% \text { of Concentrate }\end{array}$ & $\begin{array}{c}25 \% \text { EPG reduction } \\
27 \% \text { EPG reduction (non-significant) }\end{array}$ & Not tested & [58] \\
\hline Garat $^{(\circledR)}$ & Goats & FMVZ-UADY & $5.84 \%$ & $40 \%$ of concentrate & $\begin{array}{l}69 \% \text { EPG reduction* } \\
51 \% \text { fecundity reduction }\end{array}$ & PEG & [86] \\
\hline $\begin{array}{l}\text { Starbucks }{ }^{\circledR} \text { CS } \\
\text { Starbucks }{ }^{\circledR} \text { SG }\end{array}$ & Sheep & FESC-UNAM & $19.6 \%$ & $10 \%$ of diet & $\begin{array}{l}25 \% \text { EPG reduction* } \\
26 \% \text { fecundity reduction* }\end{array}$ & PEG & [28] \\
\hline $\begin{array}{l}\text { Starbucks }{ }^{\circledR} \text { CS } \\
\text { Starbucks }{ }^{\circledR} \text { SG }\end{array}$ & Sheep & Paraiso & $19.6 \%$ & $10 \%$ of diet & No EPG reduction & PEG & [85] \\
\hline
\end{tabular}

* Significant at $p<0.05$.

the concentrate feed). Goats were able to consume more SCG as it was possible to reach up to $40 \%$ of the concentrate feed. Meanwhile, the studies with sheep could only include $10 \%$ of diet. The latter is consistent with recent studies showing a greater ability of adult goats to eat more polyphenol-rich materials compared to adult sheep [41, 118] and the same was recently found for weaned animals [49]. The study with naturally infected goats showed non-significant FEC reductions (25-27\% compared to the control diet) after three weeks of ingestion of feed containing SCG [57]. The second study by Palomo-Couoh et al. (2012) [86] showed that $H$. contortus-infected goat kids consuming SCG for 4 weeks had reduced FEC by $69 \%$, and female worm fecundity by $51 \%$ compared to kids consuming the control diet. One study with sheep reported a significant reduction of FEC and worm fecundity [28] but in a second study, no $\mathrm{AH}$ activity was found although the same quantity of SCG was applied as in the first sheep trial [85]. The difference in the results between the studies could be associated with the $H$. contortus isolate used. The first study used the FESC-UNAM isolate, which is susceptible to polyphenols, and the second study used the polyphenol-resistant Paraiso isolate [20].

\section{Evidence of $\mathrm{AH}$ activity of Theobroma cacao leaves and pod husks}

An early study reported that extracts obtained from $T h$. cacao pod husks and seed husks (seed peels) displayed limited ovicidal activity (eggs remaining as morula) against $H$. contortus eggs from a dose of $600 \mu \mathrm{g} / \mathrm{mL}$ or $2400 \mu \mathrm{g} / \mathrm{mL}$, respectively. However, that same study also showed that the main activity against eggs consisted of blocking the hatching of 


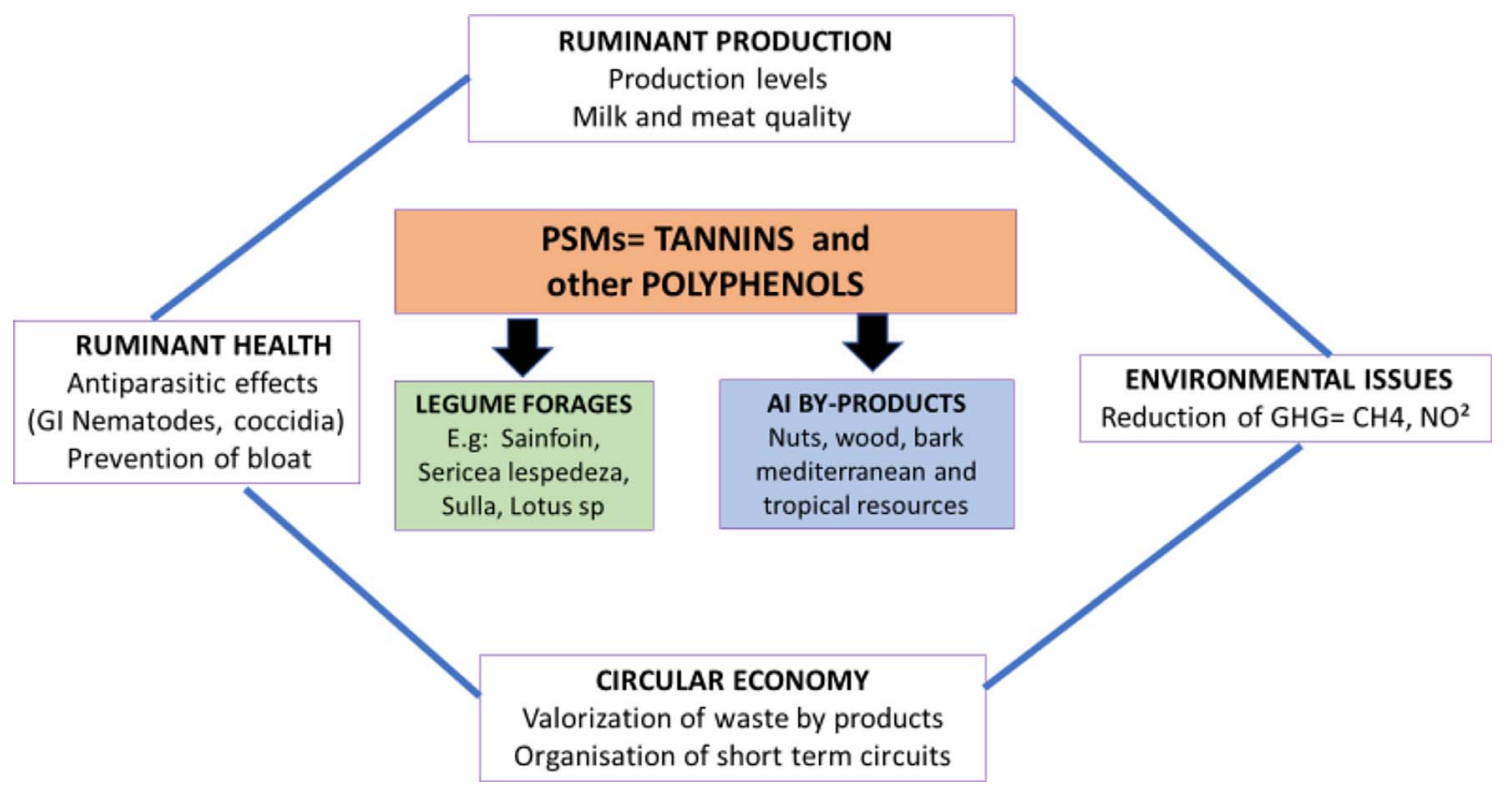

Figure 2. A summarised diagram of the various potential benefits of tannin-containing forages (e.g. sainfoin or sericea lespedeza) and/or byproducts in ruminant production in the context of agro-ecological production. Examples and results by referring to the general framework and objectives presented in Figure 1.

larvae formed within eggs. Such activity was described as larvae failing hatching [115]. A second study evaluated the in vitro $\mathrm{AH}$ activity against $H$. contortus eggs using respective acetone: water extracts obtained from the leaves and pod husks of three Mexican Th. cacao varieties. The AH activity against eggs was more evident for the FESC (polyphenol-susceptible) $H$. contortus isolate, with $\mathrm{EC}_{50}$ values $<442 \mu \mathrm{g} / \mathrm{mL}$ for husk and leaf extracts. Meanwhile, the activity against eggs for the Paraiso (putative polyphenol-resistant) isolate ranged from 2172 to $700.2 \mu \mathrm{g} / \mathrm{mL}$ in the husk extracts, and from 1115.5 to $684.8 \mu \mathrm{g} / \mathrm{mL}$ in the leaf extracts [65]. The use of PVPP showed that the activity of the Th. cacao extracts against eggs was not associated with the polyphenols contained in extracts. Thus, the PSM compounds responsible for the activity against eggs are yet to be elucidated.

The same pod husk and leaf extracts from different Th. cacao varieties were also used to evaluate their exsheathment inhibition activity against $H$. contortus $\mathrm{L} 3$ [65]. The $\mathrm{EC}_{50}$ values of husk extracts ranged from 630.5 to $554.0 \mu \mathrm{g} / \mathrm{mL}$ in the FESC isolate, and from 1068.3 to $472.7 \mu \mathrm{g} / \mathrm{mL}$ in the Paraiso isolate. Meanwhile, the $\mathrm{EC}_{50}$ values of leaf extracts ranged from 333.7 to $264.2 \mu \mathrm{g} / \mathrm{mL}$ in the FESC isolate, and from 250.2 to $192.9 \mu \mathrm{g} / \mathrm{mL}$ in the Paraiso isolate. These results clearly show that the Th. cacao extracts have stronger exsheathment inhibition activity compared to the activity against eggs of $H$. contortus. Besides, the use of PVPP suggested that the exsheathment inhibition was not associated with polyphenols for pod husk extracts of Azteca and Calabacillo varieties.

The first in vitro evidence of $\mathrm{AH}$ activity against Trichostrongylus colubriformis was recently obtained using acetone: water Th. cacao leaf extracts [64]. The Calabacillo and Azteca extracts showed similar activities $\left(\mathrm{EC}_{50}=\right.$ $335.8 \mu \mathrm{g} / \mathrm{mL}$, CI 95\% [309-362.6] and $\mathrm{EC}_{50}=387.3 \mu \mathrm{g} / \mathrm{mL}$, CI 95\% [352.5-422.2], respectively). Meanwhile, the Ceylon extract showed the best exsheathment inhibition activity
$\left(\mathrm{EC}_{50}=185.6 \mu \mathrm{g} / \mathrm{mL}, \mathrm{CI} 95 \%\right.$ [165.8-205.4]). This study confirmed that the Th. cacao leaf extracts showed good AH activity against $T$. colubriformis. Variation in activity suggests that some Th. cacao varieties could provide better activity than others, and that should be considered when testing under in vivo conditions.

A recent study determined the in vivo nutraceutical value of Th. cacao leaves against natural GIN infections of goats [37]. The Th. cacao leaves (Criollo variety) were harvested and dried indoors at room temperature. The experimental goats consumed the dry Th. cacao leaves (TCG) for 9 days and a control group (CG) consumed a conventional diet. The animals consuming the Th. cacao leaves were purposely hosting larger natural GIN infection (mean of $2228 \pm 28$ EPG), while the CG hosted milder GIN infection (mean of $709 \pm 9 \mathrm{EPG}$ ). The inclusion of Th. cacao leaves did not affect the productivity of goats, which were able to consume $>300 \mathrm{~g}$ DM of leaves/day. Such high consumption displayed by TCG goats did not affect packed cell volume or live weight, but reduced FEC by $78 \%$ compared to CG goats $(p<0.05)$. Thus, Th. cacao leaves were confirmed as a nutraceutical candidate against natural GIN infections in goats.

\section{The different modes of exploitation of AIBPs of tropical origin}

The idea behind the use of AIBPs obtained from Th. cacao and $C$. arabica may follow very different paths. We propose using the leaves and pod husks that are produced by Th. cacao farmers, which could represent added value for these two AIBPs of Th. cacao. Thus, the proposal built around the AIBP of Th. cacao should directly link cocoa farmers with ruminant farmers. On the other hand, our proposal around $C$. arabica refers to the use of the SCG, which is the by-product that results from the brewing of ground coffee at the smallest scale (home 
brewing), at coffee shops worldwide, or even the possibility of using this material at an industrial scale where instant coffee is produced. The $C$. arabica SCG approach could also be applicable to small-scale farmers who may use their own coffee waste brewed at home, or may involve linking the AIBP of coffee shops or industries with a large sheep or goat farm, or with groups of small to medium size farmers that could share the product in a more standardised manner.

\section{Conclusions}

The selection of the different AIBPs for this review aimed first at illustrating the worldwide availability of tannincontaining by-products corresponding to the worldwide distribution of GIN in ruminants. Besides this first objective, the different selected examples also aimed to illustrate the diversity of mode of applications of these resources as nutraceuticals, depending on whether they have some nutritional value, and on voluntary feed intake by sheep, goats or cattle. There are various options for delivery of AIBP to livestock, namely:

(i) direct consumption of the AIBP as potential nutraceuticals;

(ii) combination of the AIBP with a matrix of fodders (tannin-containing or tannin-free pellets);

(iii) extraction of pure active compounds from the AIBP.

To these different options correspond different pros and cons for each AIBP. These are briefly summarised in the following general SWOT analysis, which is proposed based on the currently available information for the selected AIBP. A wide variety of AIBPs have been examined for antiparasitic activity or are subject to investigations in progress; for example, different by-products of the wine industry of olive and/or citrus production, although polyphenols are probably not the sole PSMs involved in the bioactivity. A more general SWOT analysis could therefore summarise the general pros and cons of AIBPs depending on the various modes of use and according to both basic and applied research.

\section{- Strengths}

As illustrated in this review, the proof of concept of AIBPs as nutraceuticals with anthelmintic activity has been applied worldwide. This is associated with the worldwide concomitant distribution of both GIN and tannin-containing resources.

Overall, AIBPs represent potential low-cost, locally available resources containing bioactive tannins and other polyphenols, which can be proposed to ruminants and can be used directly by farmers. One of the main advantages of AIBP for any potential $\mathrm{AH}$ activity is to offer the opportunity to characterise them by measuring $\mathrm{CT}$ and to evaluate their bioactivity (e.g. potential $\mathrm{AH}$ activity in simple in vitro assays) before use as feed supplements. In the case of direct use as nutraceuticals, an evaluation of the nutritional values is also feasible (e.g. for carob, cocoa). Another obvious main advantage for the agro industries generating the by-products is to add value to resources that are usually considered waste and otherwise represent a cost for these industries.
In some circumstances (e.g. coffee, cocoa or carob), AIBPs offer options for organisation of short-circuits of use and/or commercialisation, possibly involving local enterprises. For example, in the case of tropical resources, the manures of sheep and goats can represent a source of fertilizers for coffee and cocoa cultivation, closing the loop. In this respect, the potential use of AIBPs in ruminant (or other livestock) production is an example of the circular economy in a context promoting an agro-ecological approach of animal production, with lower reliance on chemical inputs and better utilisation of locally available resources. Overall, AIBPs represent a model to the circular bioeconomy, one of the main ways to transform our economies and avoid exceeding the earth's biophysical limits [81].

With regard to further basic research, the diversity of AIBPs represent a wide range of tannins and related compounds, with a diversity of structures. This should allow us to better understand the modes of action of these polyphenols against worms, including potential synergistic interactions (Klongisriweit et al 2015) as well as their possible effects on host digestive physiology, including the gut microbiota and local immunity $[121,122]$. The synergistic interactions already shown by enhanced activity of CT derived from multiple plant species, also suggests that the evolution of resistance to active compounds by parasites is either unlikely, or in the case of the apparent adaptive resistance discussed above, overcome by a change of PSM source.

\section{- Weaknesses}

In the hypothesis of being used as nutraceuticals either directly or by incorporation in some other vegetal matrix (e.g. pellets of fodders to ensure an appropriate overall nutritional level), one of the main issues to solve for the future use of AIBPs relates to their acceptability by the different ruminant species. Palatability of the resources and, ultimately, lack of toxicity, are the first criteria to fulfil before being able to consider any health-promoting effects. In the case of incorporation of AIBPs in a matrix, the addition of flavours to stimulate voluntary food intake is an option. In the case of local use by farmers of non-traditional resources, one weakness could be related to reluctance to adapt to this novel proposed control tool. This could require some early involvement of advisors to explain the aim and to illustrate the potential benefits of incorporating AIBP in animal feed.

In the case of involvement of industrial companies (whether small or large), one weakness is the need to evaluate the economic sustainability of the market and the possible hurdles to organise the collection, preparation, storage, and distribution of the AIBPs at different scales, which might require some investments. The lack of understanding of economic viability of AIBP commercialisation by the feed-additive industry will require assessment of new potential value chains based on local circular approaches and comparing these with current approaches. It will also need to assess and compare costs, benefits and feasibility of using raw AIBP versus extraction of the active components that would increase quality and commerciality, but increase production costs.

The technological processes applied to prepare the different modes of use of AIBPs will have to preserve the bioactive 
compounds. In addition, ensuring constant quality and stability of the resources will also be one main issue to protect the health of animals but also consumers. For example, as illustrated with chestnut by-products, it has been shown that the extraction of the AIBP by technological processes, whether involving water or not, has major influences on BP quality and on future storage and conservation, e.g. propensity to contamination with fungi, moulds and potential mycotoxins. In the case of coffee and cocoa BP, as well as bark, potential contamination with soil and sand should also be considered. Last, in the hypothesis of AIBPs being considered as resources to extract purified tannins, the nature of the applied solvents can also represent a risk to evaluate, e.g. the use of organic solvents is very difficult if not impossible to handle in large-scale extraction.

It is also increasingly clear that different plant varieties, as well as other factors such as growth conditions, can affect PSM concentration and form, and consequently bioactivity. Variation due to the extraction method adds to this, such that it is difficult to ensure standard quantity and quality of PSM content. Quality control of CT and other PSM extracts from plants destined for use as nutraceuticals is a challenge and potential weakness, in general and also for AIBPs.

Finally, AIBP must be delivered to the animal, and this can be difficult during periods of grazing, which are also generally the times of maximum GIN challenge. Finding ways to align AIBP supplementation with parasite epidemiology to maximise impacts on parasite populations and their impacts on animal performance could be challenging in some livestock systems, especially those involving extensive grazing.

\section{- Opportunities}

The possible use of natural bioactive compounds to control the main parasitic infections in grazing ruminants correspond to a general public demand to reduce the use of synthetic chemicals in agriculture, and also to general promotion of organic farming systems, especially in the European Union and partner countries.

Besides the possible effects of CT-containing forages in disrupting GIN biology, the various CT-containing legumes have also been associated with other beneficial impacts within the agro-ecological context of livestock production (MuellerHarvey et al., 2019). Namely:

(i) Some other health benefits, in particular in relation to the health of the digestive tract: e.g., prevention of bloat in ruminants and also anti-coccidial effects either in ruminants [15, 104] or other species. For example, some in vitro activity against Cryptosporidium parvum have been shown with extracts of pine bark [12]. Also, in rabbits, the incorporation of chestnut BP combined with tannins of quebracho, have been associated with some anti-coccidial effects [90] confirming previous results obtained with sainfoin [58]. In pigs, the incorporation of chestnut BP has also been associated with prevention of diarrhoea [39]. Last, anti-inflammatory effects in the gut have been associated with some PSMs [4, 121].

(ii) To limit the environmental consequences of ruminant production by limiting greenhouse gas emissions, including $\mathrm{CH}_{4}$ and $\mathrm{NO}_{2}$. For example, the incorporation of hazelnut BP in the basal feed of lambs was compared to sainfoin. With both resources, the results showed lower rumen fermentability, and $\mathrm{CT}$ decreased $\mathrm{CH}_{4}$ production and protein degradability [82]. Increased supply of digestible protein has additional positive environmental outcomes by limiting reliance on feed supplementation, for example from importing soy and other protein-rich feeds that increase demand for land in sensitive areas and feed-food-wood competition; and by limiting reliance on fertilisers.

(iii) Quality of animal-derived products, including meat and milk $[38,94]$. The effects of feeding hazelnut peels on dairy ewe performances and milk quality were recently examined [17], suggesting some favourable effects on milk composition for human health.

\section{- Threats}

Three main threats can be identified which challenge the potential use of tannin-containing AIBP for the nutrition, health and production of livestock, in particular ruminants (Fig. 2).

For the moment, most of the current studies on these bioactive resources rich in natural PSMs have focused on efficacy against gastrointestinal parasites (nematodes and/or coccidia). However, there is a lack of studies on the fate of residues in animal products, either of the PSM that is the source of the benefits or of other co-occurring compounds in the source plants, including toxins and heavy metals. The issue of the regulation of these resources (as additives, complementary feeds, or veterinary medicinal drugs) can strongly affect the future development of such AIBPs. These issues also suppose the development and validation of methods to measure maximum residual values for plant bioactive compounds.

In the circular bio-economy, competition may arise between the use of by-products for several purposes. There is a general trend to identify polyphenols with anti-oxidant properties, and benefits for human health. While multiple benefits of AIBPs are encouraging for their utilisation in the circular economy, this could create competition for their use and drive up prices, reducing economic viability as animal feed. However, pharmaceutical aims may be considered the most valuable use of AIBPs [11].

Lastly, as mentioned in the section on coffee and cocoa, the question of the possible development of resistance by GIN to tannins and polyphenols is pending. Considering the longstanding interactions between hosts, parasites and PSMs from an evolutionary perspective, adaptation of GIN to key PSMs is to be expected. On the other hand, a current hypothesis on the mode of action of tannins and polyphenols on the different key stages (Egg, L3 and adult worms) of GIN seems pleiomorphic based on tannin-protein interactions [45]. This can limit the risks of development of resistance to polyphenols in worm populations. However, this hypothesis needs to be challenged and confirmed by further basic studies.

Acknowledgements. This review is based upon work from COST Action COMBAR CA16230, supported by COST (European Cooperation in Science and Technology). This is also part to the LIFE project MICLIFEED (LIFE20 CCM/GR/001703) 
In addition and more specifically:

- the co-authors of France and Finland wish to acknowledge financial help from the COMBITAN F2E project,

- the co-authors of Greece wish to acknowledge financial help from Agro4Crete and SmartWaste project,

- the co-authors of Denmark, Norway and Scotland wish to acknowledge financial help from the BarkCure project, funded by the Norwegian Research Council through the Bionær programme, grant number 268264 ,

- the co-authors of Mexico wish to acknowledge financial help from Cátedras CONACYT (project 692),

- the co-authors of Brazil were financed in part by the Coordenação de Aperfeiçoamento de Pessoal de Nível Superior - Brasil (CAPES) - Finance Code 001, and,

- the co-authors of Brazil and France wish to acknowledge financial help from the PROJECT France-Afrique Brésil.

- ERM acknowledges the support of UK Research and Innovation grant BB/S014748/1.

\section{Conflict of interest}

The authors confirm that they do not have any conflict of interest.

\section{References}

1. Acharya M, Burke JM, Miller JE, Terrill TH, Wood EL, Muir JP. 2020. Quebracho tannins aid in the control of Eimeria spp. and gastrointestinal nematodes in lambs and goat kids. Veterinary Parasitology, 288, 109295.

2. Adejoro FA, Hassen A, Akanmu AM. 2019. Effect of lipidencapsulated acacia tannin extract on feed intake, nutrient digestibility and methane emission in sheep. Animals, 9, 863.

3. Alves TP, Dall-Orsoletta AC, Ribeiro-Filho HMN. 2017. The effects of supplementing Acacia mearnsii tannin extract on dairy cow dry matter intake, milk production, and methane emission in a tropical pasture. Tropical Animal Health and Production, 49, 1663-1668.

4. Andersen-Civil AIS, Leppa MM, Thamsborg SM, Salminen JP, Williams AR. 2021. Structure-function analysis of purified proanthocyanidins reveals a role for polymer size in suppressing inflammatory responses. Communications Biology, 4, 896.

5. Athanasiadou S, Kyriazakis I, Jackson F, Coop RL. 2001a. Direct anthelmintic effects of condensed tannins towards different gastrointestinal nematodes of sheep: In vitro and in vivo studies. Veterinary Parasitology, 99, 205-219.

6. Athanasiadou S, Kyriazakis I, Jackson F, Coop RL. 2001b. The effects of condensed tannins supplementation of foods with different protein content on parasitism, food intake and performance of sheep infected with Trichostrongylus colubriformis. British Journal of Nutrition, 86, 697-706.

7. Athanasiadou S, Almvik M, Hellström J, Madland E, Simic N, Steinshamn H. 2021. Chemical analysis and anthelmintic activity against Teladorsagia circumcincta of Nordic bark extracts in vitro. Frontiers in Veterinary Science, 8, 666924.

8. Auad P, Spier F, Gutterres M. 2020. Vegetable tannin composition and its association with the leather tanning effect. Chemical Engineering Communications, 207, 722-732.

9. Bahuaud D, Martinez-Ortiz De Montellano C, Chauveau S, Prevot F, Torres Acosta JFJ, Fouraste I, Hoste H. 2006. Effects of four tanniferous plant extracts on the in vitro exsheathment of third-stage larvae of parasitic nematodes. Parasitology, 132, 545-554.

10. Batlle I, Tous J. 1997. Carob tree (Ceratonia siliqua L): Promoting the conservation and use of underutilized and neglected crops 17. Institute of plant genetics and crop plant research, Gatersleben/International Plant Genetics Resources Institute: Rome, Italy. p. 23.

11. Berbel J, Posadillo A. 2018. Review and analysis of alternatives for the valorisation of agro-industrial olive oil by-products. Sustainability, 10, 237.

12. Blomstrand BM, Enemark HL, Øines Ø, Steinshamn H, Aasen IM, Mahnert KC, Sørheim KM, Athanasiadou S, Thamsborg SM, Woolsey ID. 2021. Extracts of pine bark (Pinus sylvestris) inhibit Cryptosporidium parvum growth in cell culture. Parasitology Research (submitted).

13. Boudot C. 2014. Étude in vitro de l'activité anthelminthique de co-produits agro industriels riches en tanins et flavonoïdes. Report for the grade of Pharmacian Faculty of Pharmacy Univ Paul Sabatier Toulouse 3.

14. Bravo L, Grades N, Saura-Calixto F. 1994. Composition and potential uses of mesquite pods (Prosopis pallida L.): Comparison with carob pods (Ceratonia siliqua L.). Journal of Science Food Agriculture, 65, 303-306.

15. Burke JM, Miller JE, Terril TH, Orlik ST, Acharya M, Garza JJ, Mosjidis JA. 2013. Sericea lespdeza as an aid in the control of Eimeria spp. in lambs. Veterinary Parasitology, 193, 39-46.

16. Calderón-Quintal JA, Torres-Acosta JFJ, Sandoval-Castro CA, Alonso MA, Hoste H, Aguilar-Caballero AJ. 2010. Adaptation of Haemonchus contortus to condensed tannins: can it be possible? Archivos Medicina Veterinaria, 42, 165-171.

17. Campione A, Natalello A, Valenti B, Luciano G, Rufino-Moya PJ, Avondo M, Morbidini L, Pomente C, Krol B, Wilk M, Migdal P, Pauselli M. 2020. Effect of feeding hazelnut skin on animal performance, milk quality, and rumen fatty acids in lactating ewes. Animals, 10, 588.

18. Cenci FB, Louvandini H, McManus CM, Dell'Porto A, Costa DM, Araújo SC, Minho AP, Abdalla AL. 2007. Effects of condensed tannin from Acacia mearnsii on sheep infected naturally with gastrointestinal helminths. Veterinary Parasitology, 144, 132-137.

19. Chan JM, Day P, Feely J, Thompson R, Little KM, Norris CH. 2015. Acacia mearnsii industry overview: current status, key research and development issues. Southern Forests, 77, 19-30.

20. Chan-Pérez JI, Torres-Acosta JFJ, Sandoval-Castro CA, Hoste H, Castañeda-Ramírez GS, Mathieu C, Vilarem G. 2016. In vitro susceptibility of ten Haemonchus contortus isolates from different geographical origins towards acetone:water extracts of two tannin rich plants. Veterinary Parasitology, 217, 53-60.

21. Chan-Pérez JI, Torres-Acosta JFJ, Sandoval-Castro CA, Castañeda-Ramírez GS, Vilarem G, Mathieu C, Hoste H. 2017. Susceptibility of ten Haemonchus contortus isolates from different geographical origins towards acetone: water extracts of polyphenol-rich plants. Part 2: Infective L3 larvae. Veterinary Parasitology, 240, 11-16.

22. Charlier J, Thamsborg SM, Bartley DJ, Skuce PJ, Kenyon F, Geurden T, Hoste H, Williams AR, Sotiraki S, Höglund J, Chartier C, Geldhof P, van Dijk J, Rinaldi L, Morgan ER, von Samson-Himmelstjerna G, Vercruysse J, Claerebout E. 2017. Mind the gaps in research on the control of gastrointestinal nematodes of farmed ruminants and pigs. Transboundary and Emerging Disease, 65, 217-234.

23. Charlier J, van der Voort M, Kenyon F, Skuce P, Vercruysse J. 2014. Chasing helminths and their economic impact on farmed ruminants. Trends in Parasitology, 30(7), 361-367. 
24. Cherrah Y, Farah A, Ennabili A, Bali BE, Lachka M. 2011. Antioxidant activity, phytochemical screening, and total phenolic content of extracts from three genders of carob tree barks growing in Morocco. Arabian Journal of Chemistry, 4, 321-324.

25. Corrêa PS, Mendes LW, Lemos LN, Crouzoulon P, Niderkorn V, Hoste H, Costa-Júnior LM, Tsai SM, Faciola AP, Abdalla AL, Louvandini H. 2020. Tannin supplementation modulates the composition and function of ruminal microbiome in lambs infected with gastrointestinal nematodes. FEMS Microbiology Ecology, 96, fiaa024.

26. Correddu F, Lunesu MF, Buffa G, Atzori AS, Nudda A, Battacone G, Pulina G. 2020. Can agro-industrial by-products rich in polyphenols be advantageously used in the feeding and nutrition of dairy small ruminants? Animals, 10, 131.

27. Costa-Júnior LM, Costa JS, Lôbo Í, Soares AM, Abdala AL, Chaves DP, Batista ZS, Louvandini H. 2014. Long-term effects of drenches with condensed tannins from Acacia mearnsii on goats naturally infected with gastrointestinal nematodes. Veterinary Parasitology, 205, 725-729.

28. Covarrubias-Cárdenas AG. 2013. Evaluación del efecto antihelmíntico de un subproducto de Coffea arabica sobre un aislado de Haemonchus contortus susceptible a taninos. MSc Thesis. Universidad Autónoma de Yucatán: Mérida, México.

29. Covarrubias-Cárdenas AG, Torres-Acosta JFJ, Sandoval-Castro CA, Hoste H. 2013. In vitro anthelmintic effect of Acacia pennatula and Coffea arabica extracts on Haemonchus contortus sensitive to tannins. In: Proceedings of the 7th Novel Approaches Meeting with a session of the CA-PARA COST ACTION "Goat parasite interaction: from knowledge to control", Toulouse, France.

30. Dahal J, Ketavong S, Pardo E, Barbier E, Gay M, Jean H, Niderkorn V, Hoste H. 2018. In vitro screening of the anthelmintic effects of by-products from the chestnut industry against parasitic nematodes of sheep and goats. In: EAAP 69th Conference, 27th-30th August, Dubrovnik, Croatia.

31. Das AK, Islam N, Faruk O, Ashduzzaman M, Dungani R, Rosamah E, Hartati S, Rumidatul A. 2020. Hardwood tannin: sources, utilizations, and prospects in Tannin - structure properties biological properties current knowledge, in Aires A, Editor. IntechOpen. p. 1854-1858.

32. Denninger TM, Schwarm A, Birkinshaw A, Terranova M, Dohme-Meier F, Münger A, Kreuzer M. 2020. Immediate effect of Acacia mearnsii tannins on methane emissions and milk fatty acid profiles of dairy cows. Animal Feed Science and Technology, 261, 114388.

33. Desrues O, Fryganas C, Ropiak HM, Mueller-Harvey I, Enemark HL, Thamsborg SM. 2016. Impact of chemical structure of flavanol monomers and condensed tannins on in vitro anthelmintic activity against bovine nematodes. Parasitology, 143, 444-454.

34. Desrues O, Vargas-Magana J, Girard M, Manolaraki F, Pardo E, Mathieu C, Vilarem G, Torres-Acosta JFJ, Sandoval Castro CA, Jean H, Hoste H. 2012. Can hazel-nut peels be used to control gastrointestinal nematodes in goats? In: 11th International Goat Association (IGA) Conference. 4th CAPARA Conference, September 2012, Las Canarias, Book of abstract, p. 44.

35. Dhakal S, Meyling NV, Williams AR, Mueller-Harvey I, Fryganas C, Kapel CMO, Fredensborg BL. 2015. Efficacy of condensed tannins against larval Hymenolepis diminuta (Cestoda) in vitro and in the intermediate host Tenebrio molitor (Coleoptera) in vivo. Veterinary Parasitology, 207, 49-55.

36. Diaz Lira CM, Barry TN, Pomroy WE, McWilliam EL, LópezVillalobos N. 2008. Willow (Salix spp.) fodder blocks for growth and sustainable management of internal parasites in grazing lambs. Animal Feed Science Technology, 141, 61-81.
37. García-Ceballos CA, Ventura-Cordero J, Mendoza-López GF, González-Pech PG, Mancilla-Montelongo MG, CastañedaRamírez GS, Capetillo-Leal CM, Torres-Acosta JFJ, SandovalCastro CA. 2018. Evaluación de la inclusión de hojas de Theobroma cacao en la dieta de cabras. In: Ponencia. V Seminario Internacional y VI Nacional de Investigadores en Salud y Producción Animal SENISPA, Tunja, Boyacá, Colombia.

38. Girard M, Dohme-Meier F, Silacci P, Kragten SA, Kreutzer Bee G. 2016. Forage legumes rich in condensed tannins may increase n-3 fatty acid levels and sensory quality of lamb meat. Journal Science Food Agriculture, 96(6), 1923-1933.

39. Girard M, Thanner S, Pradervand T, Hu D, Ollagnier C, Bee G. 2018. Hydrolysable chestnut tannins for reduction of postweaning diarrhea: Efficacy on an experimental ETEC F4 model. Plos ONE, 13(5).

40. Girard M, Gaid S, Mathieu C, Vilarem G, Gerfault V, Routier M, Gombault P, Pardo E, Manolaraki F, Hoste H. 2013. Effects of different proportions of sainfoin pellets combined with hazel nut peels on infected lambs, 26th -30th August 2013. Book of abstract p 506.

41. González-Pech PG, Torres-Acosta JFJ, Sandoval-Castro CA, Tun-Garrido J. 2015. Feeding behavior of sheep and goats in a deciduous tropical forest during the dry season: the same menu consumed differently. Small Ruminant Research, 133, 128-134.

42. Hajaji HE, Lachkar N, Alaoui K, Cherrah Y, Farah A, Ennabili A, Bali BE, Lachkar M. 2011. Antioxydant activity, phytochemical screening and total phenolic content of extracts from three genders of carob tree barks growing in Morocco. Arabian Journal of Chemistry, 4, 321-324.

43. Hernández-Orduño G, Torres-Acosta JFJ, Sandoval-Castro CA, Aguilar-Caballero AJ, Reyes-Ramirez R, Hoste H, CalderónQuintal JA. 2008. In vitro anthelmintic effect of Acacia gaumeri, Havardia albicans and quebracho tannin extracts on a mexican strain of Haemonchus contortus L3 larvae. Tropical and Subtropical Agroecosystems, 8, 191-197.

44. Hoste H, Jackson F, Athanasiadou S, Thamsborg SM, Hoskin SO. 2006. The effects of tannin rich plants on parasitic nematodes in ruminants. Trends in Parasitology, 32, 253-261.

45. Hoste H, Martinez Ortiz-De-Montellano C, Manolaraki F, Brunet S, Ojeda-Robertos N, Fourquaux I, Torres-Acosta JFJ, SandovalCastro C. 2012. Direct and indirect effects of bioactive legume forages against parasitic infections: experiences with tropical and temperate forages. Veterinary Parasitology, 186, 18-27.

46. Hoste H, Torres-Acosta JFJ, Alonso-Díaz MA, Brunet S, Sandoval-Castro C, Houzangbe Adote S. 2008. Identification and validation of bioactive plants for the control of gastro intestinal nematodes in small ruminants. Tropical Biomedicine, 25, 56-72.

47. Hoste H, Torres-Acosta JFJ, Sandoval-Castro CA, MuellerHarvey I, Sotiraki S, Louvandini H, Thamsborg SM, Terrill TH. 2015. Tannin containing legumes as a model for nutraceuticals against digestive parasites in livestock. Veterinary Parasitology, 212, 5-17.

48. Hoste H, Torres-Acosta JFJ, Quijada J, Chan-Perez I, Dakheel MM, Kommuru DS, Mueller-Harvey I, Terrill TH. 2016. Interactions between Nutrition and Infections with Haemonchus contortus and related gastrointestinal nematodes in small ruminants, in Haemonchus contortus and Haemonchosis - past, present and future trends, advances in parasitology, Vol. 93. Gasser RB, von Samson-Himmelstjerna G, Editors. Academic Press. p. 239-351.

49. Jaimez-Rodríguez PR, González-Pech PG, Ventura-Cordero J, Brito DRB, Costa-Júnior LM, Sandoval-Castro CA, TorresAcosta JFJ. 2019. The worm burden of tracer kids and lambs browsing heterogeneous vegetation is influenced by strata harvested and not total dry matter intake or plant life form. Tropical Animal Health and Production, 51, 2243-2251. 
50. Janis DC. 1945. Production of industrial quebracho. Economic Geography, 21, 145.

51. Johnston CMT, Radeloff VC. 2019. Global mitigation potential of carbon stored in harvested wood products. Proceedings of the National Academy of Sciences of the United States of America, 116, 14526-14531.

52. Kim HC, Healey JM. 2001. Effects of pine bark extract administered to immunosuppressed adult mice infected with Cryptosporidium parvum. American Journal Chinese Medicine, 29, 469-475.

53. Klongsiriwet C, Quijada J, Williams AR, Mueller-Harvey I, Williamson EM, Hoste H. 2015. Synergistic inhibition of Haemonchus contortus exsheathment by flavonoid monomers and condensed tannins. International Journal for Parasitology: Drugs and Drug Resistance, 5(3), 127-134.

54. Kotrotsios N, Christaki E, Bonos E, Florou-Paneri P. 2012. Dietary carob pods on growth performance and meat quality of fattening pigs. Asian-Australasian Journal of Animal Sciences, $25,880-885$.

55. Krecek RS, Waller PJ. 2006. Towards the implementation of the "basket of options" approach to helminth parasite control of livestock: Emphasis on the tropics/subtropics. Veterinary Parasitology, 119, 270-282.

56. Kyratzis AC, Antoniou C, Papayiannis LC, Graziani G, Rouphael Y, Kyriacou MC. 2021. Pod morphology, primary and secondary metabolite profiles in non-grafted and grafted carob germplasm are configured by agro-environmental zone, genotype, and growing season. Frontiers in Plant Sciences, 11, 612376 .

57. Larsen JB, Emborg J, Kristensen KH. 2021. Dyrkede skove i Naturen i Danmark [Cultivated forests, The Nature of Denmark]. Downloaded 11 May 2021, https://naturenidanmark.lex.dk/ Dyrkede_skove.

58. LeCasble C. 2012. Le marc de café comme source atypique de tanins condensés dans le contrôle intégré des nématodes gastrointestinaux chez les petits ruminants du Yucatán, Mexique. Thèse Doctorat Vétérinaire. Ëcole Nationale Vétérinaire Alfort: France.

59. Legendre H, Saratsi K, Voutzourakis N, Saratsis N, Stefanakis A, Gombault P, Hoste H, Gidenne T, Sotiraki S. 2018. Coccidiostatic effects of tannin rich diets in rabbit production. Parasitology Research, 117, 3705-3713.

60. Lima PMT, Crouzoulon P, Sanches TP, Zabré G, Kabore A, Niderkorn V, Hoste H, Amarante AFT, Costa-Júnior LM, Abdalla AL, Louvandini H. 2019. Effects of Acacia mearnsii supplementation on nutrition, parasitological, blood parameters and methane emissions in Santa Inês sheep infected with Trichostrongylus colubriformis and Haemonchus contortus. Experimental Parasitology, 207, 107777.

61. Long R. 1991. Quebracho based polyphenols for use in wood panel adhesive system. Holz Als Roh-Und Werkstoff, 49, 485-487.

62. Mackown CT, Brown MA, Walker EL. 2011. Tannin rich peanut skins lack anthelmintic properties. Small Ruminant Research, 96, 195-200.

63. Mahdi JG. 2010. Medicinal properties of willow: a chemical perspective of aspirin discovery. Journal of the Saudi Chemical Society, 14, 317-322.

64. Mancilla-Montelongo M, Torres-Acosta JFJ, Sandoval-Castro CA. 2020. In vitro evaluation of Theobroma cacao leaf extracts against Trichostrongylus colubriformis larvae. SENISPA 2020 $=6$ Seminario Internacional y National de Investigadiores en Salud y Porudccion Animal 2020, 29th Sept. 1st October, Tunja, Boyaca, Colombia.
65. Mancilla-Montelongo MG, Gaudin-Barbier E, CastañedaRamírez GS, Canul-Velasco ML, Chan-Pérez JI, De-La-CruzCortazar A, Mathieu C, Fourquaux I, Sandoval-Castro CA, Hoste H, Ventura-Cordero J, González-Pech PG, Torres-Acosta JFJ. 2021. In vitro evaluation of the nutraceutical potential of Theobroma cacao pod husk and leaf extracts for small ruminants. Acta Parasitologica, 66, 1122-1136.

66. Manolaraki F, Sotiraki S, Skampardonis V, Volanis M, Stefanakis A, Hoste H. 2010. Anthelmintic activity of some Mediterranean browse plants against parasitic nematodes. Parasitology, 137, 686-695.

67. Marakis S. 1996. Carob bean in food and feed: current status and future potentials - a critical appraisal. Journal of Food Science and Technology, 33, 365-383.

68. Marchand S, Ketavong S, Barbier E, Gay M, Jean H, Niderkorn V, Sokrates S, Salminen JP, Hoste H. 2019. In vivo assessment of the anthelmintic effects of by-products (peels) from the chestnut industry, EAAP 70th Conference, August, Ghent, Belgium.

69. Martínez-Ortíz De Montellano C, Arroyo-López C, Fourquaux I, Torres-Acosta JFJ, Sandoval-Castro CA, Hoste H. 2013. Scanning electron microscopy of Haemonchus contortus exposed to tannin-rich extracts under in vivo and in vitro conditions. Experimental Parasitology, 133, 281-286.

70. Martínez-Ortíz-De-Montellano C, Torres-Acosta JFJ, Fourquaux I, Sandoval-Castro CA, Hoste H. 2019. Ultrastructural studies of adult Haemonchus contortus exposed to polyphenolrich materials under in vivo conditions in goats. Parasite, 26, 65.

71. Max RA, Wakelin D, Dawson JM, Kimambo AE, Kassuku AA, Mtenga LA, Craigon J, Buttery PJ. 2005. Effect of quebracho tannin on faecal egg counts and worm burdens of temperate sheep with challenge nematode infections. Journal of Agricultural Science, 143, 519-527.

72. Minho AP, Bueno ICDS, Gennari SM, Jackson F, Abdalla AL. 2008. In vitro effect of condensed tannin extract from acacia (Acacia mearnsii) on gastrointestinal nematodes of sheep. Revista Brasileira de Parasitologia Veterinária, 17, 144-148.

73. Minho AP, Filippsen LF, Amarante AFT, Abdalla AL. 2010a. Efficacy of condensed tannin presents in acacia extract on the control of Trichostrongylus colubriformis in sheep. Ciencia Rural, 40, 1360-1365.

74. Minho AP, Gennari SM, Amarante AFT, Abdalla AL. 2010 b. Anthelmintic effects of condensed tannins on Trichostrongylus colubriformis in experimentally infected sheep. Semina: Ciencias Agrarias, 31, 1009-1016.

75. Min BR, Wilson EA, Solaiman S, Miller J. 2015. Effects of condensed tannin-rich pine bark diet on experimentally infected with Haemonchus contortus in meat goats. International Journal Veterinary Health Science Research, 3, 49-57.

76. Molan AL. 2014. Effect of purified condensed tannins from pine bark on larval motility, egg hatching and larval development of Teladorsagia circumcincta and Trichostrongylus colubriformis (Nematoda: Trichostrongylidae). Folia Parasitologica, 61, 371-376.

77. Molan AL, Liu Z, De S. 2009. Effect of pine bark (Pinus radiata) extracts on sporulation of coccidian oocysts. Folia Parasitologica, 56, 1-5.

78. Morgan ER, Aziz NA, Blanchard A, Charlier J, Charvet C, Claerebout E, Geldhof P, Greer AW, Hertzberg H, Hodgkinson J, Höglund J, Hoste H, Kaplan RM, Martínez-Valladares M, Mitchell S, Ploeger HW, Rinaldi L, von Samson-Himmelstjerna G, Sotiraki S, Schnyder M, Skuce P, Bartley D, Kenyon F, Thamsborg SM, Vineer HR, de Waal T, Williams AR, van Wyk JA, Vercruysse J. 2019. 100 Questions in Livestock Helminthology Research. Trends in Parasitology, 35, 52-71. 
79. Mueller-Harvey I, Bee G, Dohme-Meier F, Hoste H, Karonen M, Kölliker R, Lüscher A, Niderkorn V, Pellikaan WF, Salminen JP, Skøt L, Smith L, Thamsborg SM, Totterdell T, Wilkinson I, Williams AR, Azuhnwi BN, Baert N, Grosse Brinkhaus A, Copani G, Desrues O, Drake C, Engström M, Fryganas C, Girard M, Huyen NT, Kempf K, Malisch K, MoraOrtiz CM, Quijada J, Ramsay J, Ropiak HM, Waghorn GC. 2019. Benefits of condensed tannins in forage legumes fed to ruminants: importance of structure, concentration, and diet composition. Crop Science, 59, 861-885.

80. Mupeyo B, Barry TN, Pomroy WE, Ramírez-Restrepo CA, LópezVillalobos N, Pernthaner A. 2011. Effects of feeding willow (Salix spp.) upon death of established parasites and parasite fecundity. Animal Feed Science and Technology, 164, 8-20.

81. Muscat A, de Olde EM, Ripoll-Bosch R. 2021. Principles, drivers and opportunities of a circular bioeconomy. Natural Food, 2, 561-566.

82. Musonda K, Barry TN, McWilliam EL, López-Villalobos N, Pomroy WE. 2009. Grazing willow (Salix spp.) fodder blocks for increased reproductive rates and internal parasite control in mated hoggets. Animal Feed Science and Technology, 150, 46-61.

83. Niderkorn V, Barbier E, Macheboeuf D, Torrent A, MuellerHarvey I, Hoste H. 2020. In vitro rumen fermentation of diets with different types of condensed tannins derived from sainfoin (Onobrychis viciifolia Scop.) pellets and hazelnut (Corylus avellana L.) pericarps. Animal Feed Science and Technology, 259, 114357.

84. Ogawa S, Yazaki Y. 2018. Tannins from Acacia mearnsii De Wild. Bark: Tannin determination and biological activities. Molecules, 23, 1-18.

85. Ortíz-Ocampo G, Chan-Pérez JI, Covarrubias-Cárdenas AG, Santos-Ricalde RH, Sandoval- Castro CA, Hoste H, CapetilloLeal CM, Torres-Acosta JFJ. 2016. Efecto antihelmíntico in vitro e in vivo de residuos de Coffea arabica sobre un aislado de Haemonchus contortus con baja susceptibilidad a taninos. Tropical and Subtropical Agroecosystems, 19, 41-50.

86. Palomo-Couoh JG, Aguilar-Caballero AJ, Torres-Acosta JFJ, Sandoval-Castro CA, Capetillo-Leal CM. 2012. Reduction of gastrointestinal nematode egg output in goats fed tannin rich fodder (Acacia penatulla) or coffee waste (Coffea arabica). Las Palmas de Gran Canaria: Spain.

87. Paolini V, Bergeaud JP, Duranton-Grisez C, Prevot F, Dorchies P, Hoste H. 2003a. Effects of condensed tannins on goats experimentally infected with Haemonchus contortus. Veterinary Parasitology, 113, 253-261.

88. Paolini V, Fouraste I, Hoste H. 2004. In vitro effects of three woody plant and sainfoin extracts on two parasitic stage of three parasitic nematode species. Parasitology, 129, 69-77.

89. Paolini V, Frayssines A, De La Farge F, Dorchies P, Hoste H. 2003b. Effects of condensed tannins on established populations and on incoming larvae of Trichostrongylus colubriformis and Teladorsagia circumcincta in goats. Veterinary Research, 34, 331-339.

90. Paolini V, Prevot F, Dorchies Ph, Hoste H. 2005. Lack of effects of quebracho and sainfoin hay on incoming third stage larvae of Haemonchus contortus in goats. Veterinary Journal, 170, 260-263.

91. Parisi F, Mancini S, Mazzei M, Forzan M, Turchi B, Perrucci S, Poli A, Paci G. 2018. Effect of dietary supplementation of a mix of chestnut and quebracho tannins on intestinal morphology, bacterial load, Eimeria spp oocyst excretion and immune response after vaccination in rabbits. American Journal Animal Veterinary Sciences, 13(3), 94-103.

92. Pena Espinoza M, Valente A, Thamsborg SM, Simonsen HT, Boas U, Einemark HL, Lopez-Munoz R, Williams AR. 2018.
Anti parasitic activity of chicory (Cichorium intybus) and the role of its natural bioactive compounds: a review. Parasite \& Vectors, 2018(11), 475.

93. Pizzi A. 2019. Tannins: Prospectives and actual industrial applications. Biomolecules, 9, 344.

94. Priolo A, Waghorn GC, Lanza M, Biondi L, Pennisi P. 2000. Polyethylene glycol as a means to reducing the impact of condensed tannins in carob pulp: effect on lamb growth and meat quality. Journal of Animal Science, 78, 810-816.

95. Priolo A, Lanza M, Bella M, Pennisi P, Fasone V, Biondi L. 2002. Reducing the impact of condensed tannins in a diet based on carob pulp using two levels of polyethylene glycol: lamb growth, digestion and meat quality. Animal Research, 51, 305-313.

96. Prosess21. 2020. Ekspertgrupperapport: Biobasert Prosessindustri [Bio-based process industry]. Report (summary in English). Nærings- og Fiskeridepartementet: Drammen. p. 1-35.

97. Quijada J, Drake C, Gaudin E, El-Korso R, Hoste H, MuellerHarvey I. 2018. Condensed tannins changes along the digestive tract in lambs fed with sainfoin pellets or hazelnut skins. Journal of Agricultural Food and Chemistry, 66, 2136-2142.

98. Quijada J, Fryganas C, Ropiak HM, Ramsay A, Mueller-Harvey I, Hoste H. 2015. Anthelmintic activities against Haemonchus contortus or Trichostrongylus colubriformis from small ruminants are influenced by different structural features of condensed tannins. Journal of Agricultural Food and Chemistry, 63, 6346-6354.

99. Ramón-Laca L, Mabberley DJ. 2004. The ecological status of the carob-tree (Ceratonia siliqua, Leguminosae) in the Mediterranean. Botanical Journal of the Linnean Society, 144, 431-436.

100. Ramsay AR, Williams AR, Quijada J, Hoste H, Thamsborg SM, Mueller-Harvey I. 2015. Anthelmintic activity of galloylated proanthocyanidins from shea meal (Vitellaria paradoxa). Planta Medica, 81, 16.

101. Ropiak HM, Ramsay A, Mueller-Harvey I. 2016. Condensed tannins in extracts from European medicinal plants and herbal products. Journal of Pharmaceutical and Biomedical Analysis, 121, 225-231.

102. Rose Vineer H, Morgan ER, Hertzberg H, Bartley DJ, Bosco A, Charlier J, Chartier C, Claerebout E, de Waal T, Hendrickx G, Hinney B, Höglund J, Ježek J, Kašný M, Keane OM, Martínez-Valladares MM, Mateus TL, McIntyre J, Mickiewicz M, Munoz AM, Phythian CJ, Ploeger HW, Aleksandra Vergles Rataj A, Skuce PJ, Simin S, Sotiraki S, Spinu M, Stuen S, Thamsborg SM, Vadlejch J, Varady M, von SamsonHimmelstjerna G, Rinaldi L. 2020. Increasing importance of anthelmintic resistance in European livestock: creation and meta-analysis of an open database. Parasite (Special issue COMBAR), 27, 69.

103. Saratsi K, Hoste H, Voutzourakis N, Tzanidakis N, Stefanakis A, Thamsborg SM, Mueller-Harvey I, Hadjigeorgiou I, Sotiraki S. 2020. Feeding of carob (Ceratonia siliqua) to sheep infected with gastrointestinal nematodes reduces faecal egg counts and worm fecundity. Veterinary Parasitology, 284, 109200

104. Saratsi K. 2021. The contribution of Mediterranean flora against gastrointestinal nematodes in small ruminants. $\mathrm{PhD}$ Thesis. Agricultural University of Athens: Athens. http://hdl. handle.net/10442/hedi/50128.

105. Saratsis A, Regos I, Tzanidakis N, Voutzourakis N, Stefanakis A, Treuter D, Joachim A, Sotiraki S. 2012. In vivo and in vitro efficacy of sainfoin (Onobrychis viciifolia) against Eimeria spp in lambs. Veterinary Parasitology, 188, 1-9.

106. Silanikove N, Landau S, Kababya D, Bruckental I, Nitsan Z. 2006. Analytical approach and effects of condensed tannins in carob pods (Ceratonia siliqua) on feed intake, digestive and metabolic responses of kids. Livestock Science, 99, 29-38. 
107. Stavrou IJ, Christou A, Kapnissi-Christodoulou CP. 2018. Polyphenols in carobs: A review on their composition, antioxidant capacity and cytotoxic effects, and health impact. Food Chemistry, 269, 355-374.

108. Steinshamn H. 2014. Bark in feed - for improved feed utilization and animal health. Bioforsk Fokus, 10, 1-53 (summary in English).

109. Stepek G, Behnke JM, Buttle DJ, Duce IR. 2004. Natural plant cysteine proteinases as anthelmintics? Trends in Parasitology, 20, 322-327.

110. Thamsborg SM, Roepstorff A, Larsen M. 1999. Integrated and biological control of parasites in organic and conventional production systems. Veterinary Parasitology, 84, 169-186.

111. Teichmann K, Kuliberda M, Schatzmayr G, Pacher T, ZitterlEglseer K, Joachim A, Hadacek F. 2016. In vitro inhibitory effects of plant-derived by-products against Cryptosporidium parvum. Parasite, 23, 1-8.

112. Torres-Acosta JFJ, Hoste H. 2008. Alternative or improved methods to limit gastro-intestinal parasitism in grazing / browsing sheep and goats. Small Ruminant Research, 77, 159-173.

113. Torres-Acosta JFJ, Hoste H, Sandoval-Castro CA, VenturaCordero J, Gonzalez Pech PG, Mancilla-Montelongo MG, Ojeda-Robertos NF, Martinez Ortiz De Montellano C. 2019. The "art of war" against gastro intestinal nematodes in sheep and goat herds of the tropics. Revista Acadamica Ciencia Animal, 17 (suppl 1), 39-46.

114. Tous J, Romero A, Hermoso JF, Ninot A, Plana J, Batlle I. 2009. Agronomic and commercial performance of four Spanish carob cultivars. Horticultural Technology, 19, 465-470.

115. Vargas-Magaña JJ, Torres-Acosta JFJ, Aguilar-Caballero AJ, Sandoval-Castro CA, Hoste H, Perez JI. 2014. Anthelmintic activity of acetone-water extracts against Haemonchus contortus eggs: interactions between tannins and other plant secondary compounds. Veterinary Parasitology, 206, 322-327.

116. Vargas-Magaña JJ, Torres-Acosta JFJ, Aguilar-Caballero AJ, Sandoval-Castro CA, Hoste H, Vilarem G, Mathieu C, ChanPérez JI. 2012. Comparación de la sensibilidad de tres ensayos in vitro para evaluar el efecto antihelmíntico de materiales ricos en taninos contra Haemonchus contortus. VII Seminario
Internacional de Parasitología Animal, Querétaro, México, p. 764-771.

117. Varmola MI, Carle JB. 2002. The importance of hardwood plantations in the tropics and sub-tropics. International Forestry Review, 4, 110-121.

118. Ventura-Cordero J, González-Pech PG, Torres-Acosta JFJ, Sandoval-Castro CA, Tun-Garrido J. 2019. Sheep and goat browsing a tropical deciduous forest during the rainy season: why does similar plant species consumption result in different nutrient intake? Animal Production Science, 59, 66-72.

119. Waller PJ. 2006. From discovery to development: current industry perspectives for the development of novel methods of helminth control in livestock. Veterinary Parasitology, 139, 1-14.

120. Waller PJ, Bernes G, Thamsborg SM, Sukura A, Richter SH, Ingebrigtsen K, Höglund J. 2001. Plants as de-worming agents of livestock in the Nordic countries: historical perspective, popular beliefs and prospects for the future. Acta Veterinaria Scandinavica, 42, 31-44.

121. Williams AR, Krych L, Ahmad HF, Nejsum P, Skovgaard K, Nielsen DS, Thamsborg SM. 2017. A polyphenol-enriched diet and Ascaris suum infection modulate mucosal immune responses and gut microbiota composition in pigs. PLoS One.

122. Williams AR, Andersen-Civil AIS, Zhu L, Blanchard A. 2020. Dietary phytonutrients and animal health: regulation of immune function during gastrointestinal pathogen infection. Journal of Animal Science, 98, skaa030.

123. Wright C. 2015. The effects of phytochemical tannincontaining diets on animal performance and internal parasite control in meat goats. College of Agriculture, Environment and Nutrition Science, Graduate Theses and Dissertations, Paper 4.

124. Yoshihara E, Minho AP, Cardim ST, Tabacow VBD, Yamamura MH. 2014. In vitro ovicidal and larvicidal activity of condensed tannins on gastrointestinal nematode infestations in sheep (Ovis aries). Semina Ciencias Agrarias, 35, 3173-3180.

125. Yoshihara E, Minho AP, Tabacow VBD, Cardim ST, Yamamura MH. 2015. Ultrastructural changes in the Haemonchus contortus cuticle exposed to Acacia mearnsii extract. Semina Ciencias Agrarias, 36, 3763-3768.

Cite this article as: Hoste H, Meza-OCampos G, Marchand S, Sotiraki S, Sarasti K, Blomstrand BM, Williams AR, Thamsborg SM, Athanasiadou S, Enemark HL, Torres Acosta JF, Mancilla-Montelongo G, Castro CS, Costa-Junior LM, Louvandini H, Sousa DM, Salminen J-P, Karonen M, Engstrom M, Charlier J, Niderkorn V \& Morgan ER. 2022. Use of agro-industrial by-products containing tannins for the integrated control of gastrointestinal nematodes in ruminants. Parasite 29, 10.

Reviews, articles and short notes may be submitted. Fields include, but are not limited to: general, medical and veterinary parasitology; morphology, including ultrastructure; parasite systematics, including entomology, acarology, helminthology and protistology, and molecular analyses; molecular biology and biochemistry; immunology of parasitic diseases; host-parasite relationships; ecology and life history of parasites; epidemiology; therapeutics; new diagnostic tools.

All papers in Parasite are published in English. Manuscripts should have a broad interest and must not have been published or submitted elsewhere. No limit is imposed on the length of manuscripts.

Parasite (open-access) continues Parasite (print and online editions, 1994-2012) and Annales de Parasitologie Humaine et Comparée (1923-1993) and is the official journal of the Société Française de Parasitologie. 